\title{
Uncertainty and Hyperinflation: European Inflation Dynamics after World War I
}

\author{
Jose A. Lopez \\ Federal Reserve Bank of San Francisco \\ Kris James Mitchener \\ Santa Clara University \\ CAGE, CEPR, CES-ifo \& NBER \\ June 2018 \\ Working Paper 2018-06 \\ https://www.frbsf.org/economic-research/publications/working-papers/2018/06/
}

\section{Suggested citation:}

Lopez, Jose A., Kris James Mitchener. 2018. "Uncertainty and Hyperinflation: European Inflation Dynamics after World War I,” Federal Reserve Bank of San Francisco Working Paper 2018-06. https://doi.org/10.24148/wp2018-06

The views in this paper are solely the responsibility of the authors and should not be interpreted as reflecting the views of the Federal Reserve Bank of San Francisco or the Board of Governors of the Federal Reserve System. 


\title{
Uncertainty and Hyperinflation: European Inflation Dynamics after World War I
}

\author{
Jose A. Lopez \\ Federal Reserve Bank of San Francisco \\ Kris James Mitchener \\ Santa Clara University \\ CAGE, CEPR, CES-ifo \& NBER*
}

May 9, 2018

\begin{abstract}
Fiscal deficits, elevated debt-to-GDP ratios, and high inflation rates suggest hyperinflation could have potentially emerged in many European countries after World War I. We demonstrate that economic policy uncertainty was instrumental in pushing a subset of European countries into hyperinflation shortly after the end of the war. Germany, Austria, Poland, and Hungary (GAPH) suffered from frequent uncertainty shocks - and correspondingly high levels of uncertainty - caused by protracted political negotiations over reparations payments, the apportionment of the Austro-Hungarian debt, and border disputes. In contrast, other European countries exhibited lower levels of measured uncertainty between 1919 and 1925, allowing them more capacity with which to implement credible commitments to their fiscal and monetary policies. Impulse response functions show that increased uncertainty caused a rise in inflation contemporaneously and for a few months afterward in GAPH, but this effect was absent or much more limited for the other European countries in our sample. Our results suggest that elevated economic uncertainty directly affected inflation dynamics and the incidence of hyperinflation during the interwar period.
\end{abstract}

JEL Codes: E31, E63, F31, F33, F41, F51, G15, N14

Keywords: hyperinflation, uncertainty, exchange rates, prices, reparations

\footnotetext{
* The views expressed here are those of the authors and not necessarily those of the Federal Reserve Bank of San Francisco or the Board of Governors of the Federal Reserve System. We thank Regis Barnichon, Vasco Cúrdia, Sylvain Leduc, Zheng Liu, Òscar Jordà, and conference participants at the 2018 SITE Conference on the Macroeconomics of Uncertainty and Volatility, 2017 CEPR Economic History Symposium, the Eighth World Congress of Cliometrics, the Federal Reserve Bank of Richmond, and the University of California, Riverside for helpful comments. We especially thank Regis Barnichon for sharing his smoothed local projection code with us. Tesia Chuderewicz, Neil Gerstein, William Hedberg, Erin Klein, Kevin Pearson, and Javier Quintero provided invaluable research assistance.
} 


\section{Introduction}

Why do hyperinflations begin? In a mechanical sense, economists have known the answer to this question at least since the monetarist revolution: money is printed in response to unsustainable fiscal policy. But ex ante, how does one identify factors that trigger hyperinflation in one country but not another, when macroeconomic indicators look broadly similar across them? For example, as a consequence of World War I, many European economies abandoned their commitments to fixed exchange rates and ran up large public debts, predisposing them to high inflation, if not hyperinflation. Belgium, Britain, France, the Netherlands, and Italy had debt-to-GDP ratios in excess of $100 \%$ and saw their price level double from 1913 (Table 1). ${ }^{1}$ Per capita direct costs associated with the war were high for both Allied and Central Power countries, and the destruction of human capital was broadly similar in countries such as France and Germany. All of these outcomes suggest a grim fiscal and monetary situation prevailed throughout Europe after the Great War, and unfavorable macroeconomic preconditions existed as much for victors as the vanquished. ${ }^{2}$

In this paper, we examine inflation dynamics in European countries immediately after the end of World War I. In particular, we analyze how pronounced economic uncertainty in certain countries contributed to their descent into hyperinflation shortly after the end of the war. The recent literature on the effects of uncertainty on macroeconomic dynamics has proposed several uncertainty measures, although a consensus on methods has not yet been established, even if the underlying premise of such a relationship is clear. ${ }^{3}$ We use a new empirical methodology for analyzing how measured uncertainty affected inflation dynamics and the incidence of hyperinflation across the ten countries in our sample. Our approach is specific as it is responsive to country-specific events and institutional strucures as well as general in that we use a common modeling framework across countries.

\footnotetext{
${ }^{1}$ Note that direct taxation to pay for increased expenditure due to the war was fairly low across Europe; e.g., $14 \%$ for Germany and 18\% for Great Britain (Balderston, 1989).

${ }^{2}$ For example, using data from Bogart (1920), Broadberry and Harrison (2005) estimate per capita net direct war costs equal to $\$ 766$ for Great Britain, $\$ 613$ for France, $\$ 343$ for Italy, $\$ 557$ for Germany, and $\$ 352$ for Austro-Hungary. Using war deaths as a percentage of the population, the same authors estimate that relative to prewar stocks, human capital declined by $7.2 \%$ in France and $6.3 \%$ in Germany.

${ }^{3}$ Jurado et al. (2015) make a distinction between different types and measures of uncertainty; namely, measures reflecting financial market uncertainty - such as Bloom (2009) and our proposed measure - and measures reflecting broader macroeconomic uncertainty. Questions of how these different measures influence macroeconomic dynamics remain a topic of debate; see Ludvigson et al. (2018) and Carriero et al. (2018) for opposing empirical conclusions.
} 
In particular, we construct a measure of uncertainty using a new inter-war dataset of daily exchange rates for ten European countries. From these high-frequency data, we develop country-specific measures of uncertainty based on monthly, realized volatility (RV). Although these RV measures were elevated across Europe after World War I, we show that they were pronounced in Germany, Austria, Poland, and Hungary (GAPH) prior to their hyperinflations. In particular, the RV measures for GAPH were many times larger than that of the Netherlands, which was neutral during the war and which we use as a benchmark for comparison. A detailed examination of contemporary news sources suggests high RV months are associated with events that contributed to policy uncertainty, and GAPH experienced such events with greater frequency and magnitude. We show that the high degree of measured uncertainty in GAPH was associated with weak fiscal positions, protracted political negotiations over reparations payments, and unresolved disputes regarding national borders and the apportionment of the Austro-Hungarian imperial debt. In contrast, the other European countries experienced some spikes in RV that can be associated with events that increased economic policy uncertainty, but they were considerably smaller in magnitude and less persistent.

The RV measure of uncertainty appears related to the inability of policymakers in GAPH to formulate and commit to credible fiscal policies, and thus suggests a causal link between uncertainty and inflation dynamics - a point alluded to, but not formally tested, in Sargent (1982). ${ }^{4}$ To test for causality more formally, we embed our measure of uncertainty within a reduced-form macroeconomic model that includes changes in inflation, industrial production, and notes outstanding at a monthly frequency. Using results based on smoothed local projections (SLP), a recent innovation by Barrichon and Brownlees (2017) that permits inference on the effects of shocks in small samples, we assess the effects of uncertainty on macroeconomic conditions prior to the start of hyperinflation for each GAPH country as well as for six other countries that did not tip into hyperinflation.

For GAPH, the SLP results show that increased uncertainty causes a contemporaneous rise in inflation as well as for the few months immediately following the shock. For example, in Germany, the results suggest that a one-standard-deviation increase in policy uncertainty leads to a contemporaneous increase in inflation of about 8 percentage points and another 3 percentage points in the subsequent month. We find similar patterns and larger magnitudes for

\footnotetext{
${ }^{4}$ In particular, Sargent (1982, pg. 75) state that "[f]rom the viewpoint that the value of a state's currency and other debt depends intimately on the fiscal policy it intends to run, the uncertainty about the reparations owed by the German government necessarily cast a long shadow over its prospects for a stable currency."
} 
the three other countries that experienced hyperinflation. Moreover, in the months just prior to when hyperinflation broke out in GAPH, monthly shocks to RV were some of the largest observed across the whole sample period. By contrast, for the other European countries with lower RV measures, the effect of increased uncertainty on inflation is absent or near zero in magnitude. For example, our results for France show that a one-standard-deviation increase in uncertainty has no effect on its inflation rate.

These findings demonstrate the utility of our methodology as it permits comparisons between countries, such as Germany and France, for example, which were on opposite sides of the reparations imbroglio as a payer and recipient, respectively. The empirical results thus elucidate how greater economic policy uncertainty contributed to accelerated inflation in Germany, but not in France. Further, our methodology allows one to incorporate many countryspecific policy narratives emphasized by historians of post-WWI Europe. For example, it helps us understand how uncertainty around issues such as the size and settlement of reparations in Germany could have contributed to driving inflation expectations further into a negative spiral (Webb 1986).

Our paper also contributes to several strands of the literature in economics. First, it complements recent research initiated by Bloom (2009) that examines the relationship between uncertainty and macroeconomic outcomes. Our research extends the work by Bloom et al. (2015) and subsequent related papers by focusing on uncertainty's effects on inflation, a macroeconomic outcome that has received comparatively less attention than investment and output. ${ }^{5}$ Our conjecture - that policy uncertainty is critical for understanding interwar European inflation dynamics - also builds on research describing how the hyperinflations of the early 1920s resulted from unbalanced fiscal and monetary policy (Cagan 1956, Sargent 1982, and Dornbusch 1982). Our analysis focuses on the period prior to the start of hyperinflation in order to better understand the role of measured uncertainty as a driver of inflation dynamics. We extend these earlier treatments by providing a quantitative modeling framework that can account for the differential inflation dynamics across Europe and that helps explain why GAPH, in particular, experienced hyperinflation.

\footnotetext{
${ }^{5}$ For example, Leduc and Liu (2016) found that for post-war U.S. data, an increase in uncertainty leads to an increase in unemployment and a decline in inflation; see also Caggiano et al. (2014) and Gilchrist et al. (2014). Vavra (2014) provides a model and empirical results linking uncertainty shocks to inflation and output growth. Bianchi and Melosi (2017) show that economic uncertainty linked to fiscal policy contributed to inflation dynamics during the Great Recession in the U.S.
} 
Our research also relates to the extensive literature on central bank independence. In particular, Bordo and Siklos (2015) show that central bank governance and effectiveness (i.e., fewer policy errors) play important roles in preventing a loss of credibility and control over inflation dynamics. ${ }^{6}$ As we describe, polities were fractured as a result of World War I, destroying the old fiscal and monetary order that had existed under the classical gold standard. The efforts of all nations to reorganize and establish new operating norms for their economies was reflected in higher levels of measured uncertainty, although importantly to varying degrees. The success and failure of these efforts are tracked by measured uncertainty and are shown to affect inflation in GAPH in our econometric analysis.

Finally, our analysis relates to recent studies on fiscal policy shocks. One strand seeks to quantify how uncertainty around the timing, magnitude, and composition of fiscal policies fundamentally influence medium-term macroeconomic projections and thus policy actions designed in reaction to a given perceived economic situation (Paredes et al., 2015). Another shows that unexpected changes in fiscal volatility shocks had a sizable adverse effect on U.S. economic activity in the late twentieth century (Fernández-Villaverde et al., 2015). The interwar period provides a clear parallel to the important avenues of how fiscal policy uncertainty influences the broader macroeconomy as examined in these papers. In many parts of post-WWI Europe, uncertainty over reparation payments, border disputes, and legacy debt obligations conspired with limited tax bases and political events to weaken policymakers' abilities to provide direction over the future path of tax and spending policies that might have helped to stabilize inflation rates in GAPH.

\section{Economic Policy Uncertainty in Europe after World War I}

World War I has been described as a watershed moment in European economic history. The war destroyed property and killed large numbers of soldiers and civilians. Old imperial powers were dissolved and new nation states were formed. Ethnic groups were involuntarily separated across new borders, and armed conflicts and border disputes continued even after treaties were drawn. The Great War left a legacy of fractured states grappling with high unemployment, industrial dislocation, and high national debts. Existing trade flows were disrupted and then reorganized, often in patterns that did not resemble the old ones. As a result, policymakers across the continent struggled to find their footing, often attempting to replicate

\footnotetext{
${ }^{6}$ See also Bordo and Siklos (2014) and Bordo and MacDonald (2002).
} 
institutions of the past, such as the gold standard, even though fundamental political and economic change had occurred.

Table 1 shows the fiscal burden that resulted from the war. Debt-to-GDP ratios (for countries that existed pre- and post-WWI) rose significantly, suggesting that, in the absence of rapid economic growth, new taxes and controls on spending would be necessary in the 1920s to return to prewar ratios. Because much of the spending on the war was monetized, prices across Europe rose considerably, as shown in the last column of Table $1 .{ }^{7}$ Given such widespread economic dislocation in the wake of the Great War, it is not obvious ex ante which countries in Europe might subsequently experience hyperinflation. For example, in addition to the situation shown in the table, France ran budget deficits and financed them through money creation and increased national debt in the early 1920s (Fraser and Taylor, 1990).

How does one identify the likelihood of a particular country experiencing hyperinflation given macroeconomic indicators at war's end that look broadly similar across Europe? Being on the winning or losing side of a war appears insufficient for determining which countries subsequently experienced hyperinflation. The Central Powers of Bulgaria and Turkey, the successor state to the Ottoman Empire, experienced very substantial increases in prices between 1914-25 (more than 3000\%), but prices never increased by more than double in any given year. Czechoslovakia - a newly formed state carved out of a losing Central Powersaw its prices rise by roughly $1600 \%$ between 1914 and 1921, but prices stabilized thereafter. Sargent (1982) emphasized that this new country, in contrast to another new one like Poland, succeeded in reducing uncertainty over its budget prospects and did not experience hyperinflation. ${ }^{8}$ On the other hand, Russia, initially part of the victorious Triple Entente (until it withdrew from the war following the Bolshevik Russian), did experience hyperinflation. ${ }^{9}$

We hypothesize that pronounced macroeconomic policy uncertainty in particular European countries was an important driver tipping countries into hyperinflation. We consider policy uncertainty to include direct policy actions, such as budget expenditures, as well as indirect activities, such as negotiations over war reparations and border disputes. Our focus on uncertainty follows a recent strand of the literature, beginning with Bloom (2009), which shows how uncertainty can influence macroeconomic outcomes.

\footnotetext{
${ }^{7}$ Sargent (1982), Eichengreen (1995), Ferguson (1975).

${ }^{8}$ Similarly, Japan, Italy, and Germany, all losers in World War II, did not subsequently experience hyperinflation.

${ }^{9}$ Limitations in monthly macroeconomic data for Russia prevent us from including this country in our empirical analysis.
} 
Several unresolved political issues cast a pall over all of postwar Europe and proved counterproductive for generating credible fiscal policy. The most widely known of these was the intractable debate over reparations payments. As laid out in the Treaty of Versailles, the Allies paradoxically acknowledged that Germany lacked the resources to pay, but also insisted on payment:

"The Allied and Associated Governments recognize that the resources of Germany are not adequate... to make complete reparation for all such loss and damage. The Allied and Associated Governments, however, require, and Germany undertakes, that she will make compensation for all damage done to the civilian population of the Allied and Associated Powers." (Articles 231-2, Treaty of Versailles)

The individual treaties struck with other belligerents - namely, the Treaties of Saint-Germainen-Laye (1919) and of Trianon (1920) that established Austria and Hungary, respectively, as independent states - similarly specified that reparations were to be paid.

Notably, all three treaties did not specify the total amount or number of years over which payments would have to be made. Instead of providing precise terms for payment of damages, a political entity, known as the Reparations Commission (RC), was charged with working out the details. The RC met repeatedly after the treaties were concluded - in San Remo (April 1920), Bath, Hyde, Spa (July 1920), and Brussels - but the gap between what the Allies sought and what Germany and others were willing to pay remained large. In January 1921, France demanded 226 billion gold marks (\$94 billion). Germany's counter proposal was just 50 billion gold marks ( $\$ 21$ billion) (Boemke, 1998, p. 410). Meanwhile, the U.S. Congress failed to ratify the Versailles treaty and was thus reduced to "observer status" as the negotiations dragged on, leaving the conversation among only Europeans who often found themselves at loggerheads. On May 5, 1921, four days after the deadline initially imposed on the $\mathrm{RC}$ for reaching an agreement and nearly two years after the treaty was signed, a deal was finally struck with Germany whereby it would pay 123 billion gold marks ( $\$ 51.25$ billion).

In Germany, reparations began taking their toll even before a final agreement was reached..$^{10}$ The Versailles Treaty had specified that 20 billion gold marks ( $\$ 4.76$ billion) would be paid immediately to provision occupying armies and for a variety of deliveries including ships, financial securities, natural resources (e.g., coal and timber), livestock, and agricultural products. Between 1920 and 1922, the young Weimar Republic ran a budget deficit as

${ }^{10}$ The constitution creating it was signed on August 11, 1919. 
reparations payments replaced armaments as the single biggest item in the budget - absorbing 48\% of it between April 1920 and March 1923 (Young, 1925). Sargent (1982, p.73) argues that, if reparations payments were excluded, Germany's budget deficit was not unsustainable until 1923. The final agreement reached on reparations also proved quite costly from a political standpoint. Adolf Hitler denounced the London payments schedule and began to attract large crowds that were unhappy with the treaty's terms. Walter Rathenau - founder of the German Democratic party, foreign minister of the republic, and advocate of fulfilling Germany's obligations as specified in the treaty - was assassinated on June 24, 1922 by right-wing extremists. In that same year, the RC declared Germany to be in default for its failure to deliver a shipment of timber.

The issues were similar in Hungary and Austria. The amount of Austrian reparations was not fixed in the Treaty of Saint Germain, and the country's financial situation remained murky until the RC determined its obligations. Austria's constitutional courts made the claim that since the country was new as of 1918 and was therefore not obligated to pay obligations that arose out of the war, but the signing of the international treaty suggested this legal argument would not satisfy foreign expectations (Dumberry, 2007, p. 102). Food and raw material shortages plagued the economy after the War and placed pressing financial burdens on the new government. It responded by providing both food relief and unemployment benefits. Its expenditures outpaced revenue growth, and the budget deficit expanded rapidly between 1919 and 1921. Austria could not resolve its budget problems and went bankrupt before reparation payments began.

Hungary's total reparations payment was also not fixed in the Treaty of Trianon, but was finally set in 1924 at 200 million gold crowns. In the intervening period, budget gridlock ensued. In 1920, the minister of finance, Lorant Hegedus, drafted a financial program that reduced budget expenditures, sought tax reform, and strove for deflation, but the program was met with opposition because of internal disagreement regarding payments to the Allies. As Sargent (1982) noted, "[t]his circumstance alone created serious obstacles in terms of achieving a stable value for Hungary's currency and other debts, since the unclear reparations obligations made uncertain the nature of the resources to back those debts." The budget situation was further complicated by the fact that the successor states to Hungary were supposed to 
compensate it for the biencedes (Hungary's former property), but this amount was never fixed, and the issue remained unsettled through the 1920s. ${ }^{11}$

The victors of World War I also faced fiscal uncertainty as a result of the failure to resolve the reparations question (Young, 1925, p.8). Physical damage from the war was concentrated in northeastern France and Belgium, and reconstruction of the war-ravaged areas required revenue. At best, Allied soldiers who were fortunate enough to return from the battlefield faced diminished employment opportunities (overcapacity in steel, coal, and agricultural production), and at worst, destroyed communities. Adding to these domestic problems were the large international debts that Great Britain and France had accumulated during the war. Both countries had liquidated foreign assets to finance part of the war and then had turned to external finance to cover their growing needs as the war dragged on. Making post-WWI repayment more complicated was France's insistence that it would only service debts to the U.S. (its largest creditor) if they were fully securitized by future German reparations. This position made it difficult for France to obtain new credit from U.S. sources (Ritschl and Straumann, 2010). Creditors, such as those in the U.S., had no incentive to forgive the debts, which only intensified pressure to seek fiscal solutions by demanding large reparation sums from the former Central Powers.

Uncertainty over borders was a second important issue that increased uncertainty over policy decision-making in post-WWI Europe, making it difficult to forecast expenditures (e.g., securing and policing borders) and derive revenues from disputed areas. Border disputes also contributed to continued high military expenditure in many European countries even after the war ended, adding significantly to treasury obligations and budget deficits (Young, 1925, p.8), and creating uncertain future fiscal obligations so long as disputes remained unresolved. For example, the German Republic accepted its new western borders, but still faced uncertainty over territorial integrity in this direction since France and Belgium were using the threat of invasion as a "stick" in negotiations over reparations payments. Germany's fears were eventually realized in 1923, when the two countries jointly occupied the Ruhr. To the east, Germany failed to fully accept the borders demarcating the newly-formed states of Poland and Czechoslovakia. Territorial uncertainty was exacerbated by France's attempt to impose a cordon sanitaire to hem in the "diseased nation" of Germany through its mutual-assistance alliances with these two new nations.

\footnotetext{
11 The debt was canceled in 1930.
} 
Austria suffered immediate financial troubles as a result of having no natural borders defined by ethnicity or production, and the dismembering of the Austro-Hungarian empire led to serious economic dislocation as new boundaries dissected railroad lines (regardless of their system) as well as production (e.g., separation of iron and coal mines from steel mills and the spindling of cotton from the looms and finishing plants) (Prochnik, 1922). The newly-formed nation of Poland was weighed down by four border disputes (two with Czechoslovakia, and one each with Germany and Lithuania) and a war with Soviet Russia, creating uncertainty as to whether the country would even last. In order to secure its borders, the Polish government committed large sums to the military; defense expenditure accounted for 53\% of the budget deficit and one third of the nation's budget in the early 1920s (Durand, 1922). The region of Upper Silesia was only forcibly removed from Germany and incorporated into Poland in June 1922 by the League of Nations, after a plebiscite mandated by the Versailles Treaty failed. Poland's border disputes and war with the Soviet Russia were slowly and fitfully resolved, dragging on from 1919 to 1921 . The League of Nations attempt to resolve the dispute with Lithuania simply by imposing a border failed to resolve the dispute before Poland tipped into hyperinflation.

Finally, uncertainty over economic policy resulted from unresolved issues regarding the formation of new states out of the former Austro-Hungarian Empire - namely, Austria, Hungary, Czechoslovakia, Poland, and the Kingdom of Slovenes, Croats, and Serbs. Internal political developments - most prominently, the rapid rise of communism in postwar Europe further threatened the durability of these policies and governments. The successor states to the Austro-Hungarian Empire struggled with diminished or non-existent state capacity. Hungary was reduced to $33 \%$ of its former size and was left with few raw materials for inputs into industrial production, a reduced internal market, and no access to the sea, which diminished its capacity for international trade (Jonas, 2016). Upon dissolution, political chaos ensued. Bela Kun's communist regime and the Romanian occupation of Budapest (August-November 1919) delayed state formation and the ability to collect revenue. Further, the assignment of the existing debt of the Austrian Monarchy needed to be settled. Interest payments were suspended in 1919, and it was not until the Innsbruck Protocol of 1925 was signed that the existing unsecured debt was formally apportioned as follows: $41.7 \%$ to Czechoslovakia; $36.8 \%$ to Austria; $13.7 \%$ to Poland; $4.1 \%$ to Italy; $2 \%$ to Yugoslavia; and $1.6 \%$ to Romania. 
The rise of communist movements further contributed to uncertainty in many European countries after WWI. For example, although socialists were instrumental in forcing Kaiser Wilhelm II to abdicate and establishing the Weimar Republic in Germany, more radical left-wing factions, including the Sparticus League (led by Karl Liebknecht and Rosa Luxemburg), committed to organized violence in an attempt to establish a Soviet-style communist government. The fledgling German government was forced to commit troops and resources to suppress these violent rebellions in regions such as Bavaria, even after the Republic had been declared. Industrial councils in both Germany and Austria were introduced in 1919 and 1920 in order to appease organized labor and reduce the threat of communist uprisings. Austria went one step further in using social programs to diffuse the growth of communism, introducing unemployment insurance; however, as noted above, its generous provision of social programs were leading to massive increases in expenditure without concomitant increases in revenue. And in Poland, the threat of communism came first and foremost from the East, via the border war with the Soviet Russia.

\section{Measuring Uncertainty}

As Obstfeld and Rogoff (1983) show, since households take into account future inflation when determining how much money to hold today, multiple equilibria for the path of inflation can arise. Inflation could simply depend on the growth rate of money over the growth rate of output, as in a monetarist model, or it could depend on other factors, including the intertemporal government budget constraint, as emphasized in models of the fiscal theory of the price level. For example, Woodford (1995) examines how a government's decision on how to finance its budget is crucial to the path of inflation. Further, news that causes agents to believe that expected primary surpluses will be smaller in the future can result in unanticipated inflation in the present - even before it shows up in a country's budget balance (Davig and Leeper, 2011).

Our approach to understanding how economic uncertainty translates into inflation dynamics allows for the possibility that policy news - whether fiscal, monetary, and even geopolitical - may influence the path of inflation today and in the future, regardless of whether the price-level path veers away from the path of the money stock as would be the case in a model of the "pure" fiscal theory of the price level (McCallum and Nelson, 2005). Specific to our analysis, Sargent (1982) argues "that the European inter-war hyperinflations grew out of 
persistently active fiscal policies that forced monetary authorities to adjust the money stock passively to meet higher average levels of government deficits." 12

As we have discussed, in Europe, unresolved political issues and weak state capacity contributed to uncertainty over borders, the size of national debts and other fiscal obligations as well as an inability to generate revenues to support them. However, since fiscal policy uncertainty was pervasive, our empirical strategy for testing its influence on inflation dynamics needs to permit for the possibility that hyperinflation could have occurred in any European country. We thus develop country-specific measures of uncertainty so that we can make withincountry comparisons (i.e., to assess whether uncertainty is a driver of inflation and of experiencing hyperinflation) and cross-country comparisons (i.e., to determine whether countries that experienced hyperinflation had more pronounced measures of uncertainty relative to that existing in other parts of Europe).

To do so, we follow the methodology introduced in Bloom (2009) and extended by subsequent research that measures uncertainty and examines the properties of these measures on their own and in relation to the macroeconomy. In particular, we focus on the volatility of financial market variables as our measure of economic uncertainty. Bloom (2009) created an uncertainty index based on the volatility of daily U.S. stock returns, and Baker and Bloom (2013) show that bond yields, exchange rates, and GDP-forecast volatility are additional suitable proxies for uncertainty. Similar proxies, such as the option-based VIX index of stock market volatility, have been used as uncertainty measures in more recent papers. For example, Baker et al. (2016) find a high correlation between the VIX index and other uncertainty measures. Gilchrist et al. (2014) measure uncertainty using variations in corporate bond spreads and find that uncertainty measured in this way has a strong effect on business investment.

Other measures have been created; for example, Bloom et al. (2015) construct a measure of U.S. "economic policy uncertainty" (EPU) based on newspaper coverage frequency. They found that their EPU measure influences aggregate investment, consumption, and employment. Jurado et al. (2015) generate an uncertainty index from the residual of factorbased macroeconomic model and show that this measure identifies fewer periods of elevated uncertainty as compared to uncertainty measures relying on financial market data.

\footnotetext{
${ }^{12}$ As pointed out in Leeper (1991), one can also consider the possibility that shocks to real debt can generate current or future money creation.
} 
Based on our desire to maximize country coverage in the 1920s and to use a wellestablished measure of uncertainty, we hand collected daily exchange-rate data from issues of the Commercial and Financial Chronicle over the years 1919 to $1925 .{ }^{13}$ Using these data, we compute the monthly, realized volatility (RV) based on daily, logged first differences of the countries' foreign exchange spot prices in the New York trading market. ${ }^{14}$ Exchange rates are a particularly useful asset price for measuring uncertainty since they capture both real-time economic and political "news" specific to a country as well as information about a country's price dynamics during periods of economic instability. ${ }^{15}$ Such RV measures have been shown to be reasonable and consistent proxies for the true, but unobservable, variance in financial time series (Andersen et al. 2003).

Accordingly, our FX-based approach provides a country-specific, high-frequency measure of economic policy uncertainty based on public data from the currency markets. An important feature of the underlying data is that they are based on exchange-rate trading in New York City, a foreign exchange market whose institutional features and market microstructure were not affected by events on the ground in Europe. In addition, previous research on the interwar period supports the notion that foreign-exchange markets were well functioning. For example, Frankel (1977) provides empirical evidence that the exchange market for German Reichsmark operating in London was efficient. ${ }^{16}$ As such, RV should accurately reflect how economic and political news affected a country's policy affairs without being polluted by distortions due to country-specific marketplace characteristics.

We compute RV as follows. For a given month, we calculate the average of the squared daily, demeaned log first differences of an exchange rate as a consistent estimate of the true, but unobservable, variance of monthly changes in the exchange rate; i.e.,

$$
\mathrm{RV}_{\mathrm{kt}}=\frac{1}{\mathrm{~N}_{\mathrm{t}}-1} \sum_{\mathrm{i}=1}^{\mathrm{N}_{\mathrm{t}}-1}\left(\Delta \mathrm{x}_{\mathrm{ki}+1}-\mu_{\mathrm{kt}}\right)^{2}
$$

\footnotetext{
${ }^{13}$ As noted by Gilchrist et al. (2014), there is no single objective mesure of economic uncetainty used in the literature. Accordingly, we focus on a measure that has been used previously and that war-time events did not disturb its functioning. This structure should ensure that our measure provides clear signals on "news" in the sample countries.

${ }^{14}$ Baillie et al. (1993) examine weekly exchange-rate volatility during this period based on data from Einzig (1937), which was sourced from the Commerical and Financial Chronicle. Peel and Spira (2015) examine the consistency of these two data sources.

${ }^{15}$ In his description of interwar hyperinflations, Sargent (1982) provides examples of purchases of foreign assets and capital controls, which suggest how important exchange rates were to the economic environment of the time. For further discussion of the German hyperinflation and exchange rates, see Frankel (1977, 1980), Salemi (1980), and Webb (1986).

${ }^{16}$ See also the follow-up discussion in a comment by Salemi (1980) and a response by Frankel (1980).
} 
where $\mathrm{k}$ is a country index; $\mathrm{N}_{\mathrm{t}}$ is the number of trading days in month $\mathrm{t} ; \Delta \mathrm{x}_{\mathrm{ki}+1}$ is the change in the logged foreign currency exchange rate for country $\mathrm{k}$ from day $\mathrm{i}$ to $\mathrm{i}+1$ in month $\mathrm{t}$; and $\mu_{\mathrm{kt}}$ is the average value of these changes in month t. Since these are measures of scale deviations, we can readily compare them in relative terms, to describe the series themselves and provide insight into their cross-sectional and time-series behavior. As displayed in Table 2, realized volatility has a reasonable degree of cross-sectional and time-series variation. Notably, the GAPH countries shown in the first four columns generally have higher RV values and exhibit upswings leading into their observed hyperinflation periods. These characteristics are especially pronounced for Germany in 1923 . The average RV values for the non-hyperinflation countries are clearly lower, although they do exhibit some interesting spikes earlier in the sample.

Variation in RV can be examined in more detail in time-series plots of individual countries. Figures 1-4 display realized volatility from July 1919 to December 1925 relative to the initial RV value for the Netherlands RV series; this country's initial was selected as a benchmark for comparison since it was neutral during the war and it has exchange rate data for the entire sample period. Figure 1 compares the relative RV measures for the UK and for the Netherlands (relative to its initial value). These two exhibit the lowest RV measures across our sample of countries. Netherland's RV measure in January 1920 is much higher relative to its normalizing observation in July 1919. As we discuss in greater detail in the next sub-section, changes in month-to-month RV can be triggered by "news" of various types. For example, Netherland's RV measure spikes to 3.0 in January 1920, which can likely be attributed to the Netherland's decision to join the League of Nations and its refusal to hand over Kaiser Wilhelm as a war criminal under the Treaty of Versailles. After the peak in early 1920, the Dutch RV series declines steadily and reaches a low of 0.1 by the end of the sample in December 1925 . The UK measure follows a similar pattern, although it exhibits much more volatility in early 1920. These patterns suggest that uncertainty in the Dutch and UK economies and political environments, while relatively elevated shortly after the end of the war with the November 1918 armistice, declined steadily over the sample period.

Figure 2 shows the RV measures for four other European countries that, ex post, did not experience hyperinflation. Belgium, Czechoslovakia, France, and Italy clearly exhibit much higher peaks and are more volatile relative to the Dutch and UK benchmarks, reaching levels that are ten to twenty times larger than the Dutch benchmark value. In fact, the Belgian 
series (in red) was about forty times the benchmark on two occasions. ${ }^{17}$ This degree of variation in the uncertainty measures speaks to the wide variation in economic conditions and fiscal policy making environments across post-war Europe. For example, France felt justified in running large budget deficits, believing Germany would eventually pay reparations for the reconstruction of territories destroyed or damaged during WWI. The French finance minister Poincare more or less proclaimed this in his famous quip "le Boche paiera tout," or roughly, the Germans will pay for everything. And, in order to enforce their claim to reparations and secure borders shared with Germany, France maintained significantly higher budget shares of military spending into the early 1920s. Note that the RV measures for France and Belgium spike to nearly ten before and during the occupation of Germany's Ruhr Valley in January 1923.

Figures 3 and 4 show the RV dynamics for GAPH, countries that eventually experienced hyperinflation. Figure 3 depicts the RV measure only for Germany since it experienced the most dramatic hyperinflation of the countries in our sample. The magnitude of the economic uncertainty reflected in the series is immense. In October 1923, after the hyperinflationary dynamics had started and the new Rentenmark was being introduced to replace the Reichsmark, it is nearly 4,500 times larger than the Dutch benchmark,. The series declines to near zero in early 1924 due to a decline in trading in the currency. ${ }^{18}$ Figure 4 also depicts the German RV series, but truncates the series at 250 times the Dutch benchmark in order to allow comparison with Austria, Hungary, and Poland. While less volatile than the German RV measure, these three countries display much higher RV values than those observed for the non-hyperinflationary countries. Their RV values are commonly fifty to 100 times the Dutch benchmark. The elevated levels suggest that the movements of these countries' exchange rates were larger and more affected by the arrival of news, suggesting that that this news contained more information on the current and future success of these countries' policy decisions. Finally, Czechoslovakia provides an interesting comparison to GAPH. As shown in Table 2, Czechoslovakia, a new country carved out of the Austro-Hungarian Empire, had an annual average RV in 1920 that was comparable to Germany and Hungary. However, as shown

\footnotetext{
17 The first spike in March 1921 appears related to Belgium's stated commitment to enforce German reparations by sending additional troops to the Rhineland. The second in April 1924 occurred when the Premier announced that Belgium's budget would no longer state a reliance on German reparations and that budget neutrality would have to be achieved through domestic tax revenues.

${ }^{18}$ According to the foreign exchange tables in the Commercial and Financial Chronicle, New York quotation of the Reichsmark continued through October 1924 when Rentenmark trading began to be reported.
} 
in Figure 2, Czechoslovakia's RV measure declined notably after August 1922. As we describe below, and in contrast to the GAPH countries, Czechoslovakia's policy environment improved considerably in the early 1920s, reducing measured economic policy uncertainty.

\section{Realized Volatility and Policy Uncertainty}

We now examine how closely realized volatility is associated with country-specific news related to policy uncertainty. Following our discussion in Section IIA, we utilize historical newspapers, secondary sources, and archival collections of the League of Nations to code events and governmental actions that would directly or indirectly influence economic policymaking as well any significant news unrelated to policy uncertainty (weather shocks, crop disasters, etc.). Table 3 displays news in the ten months with the largest RV values prior to the start of the hyperinflations in the GAPH countries. ${ }^{19}$ The table demonstrates several interesting aspects of the post-WWI economic environment. First, in nearly all of the highest RV months across our sample, countries experience events that could likely affect economic policy. ${ }^{20}$ Second, the highest RV months capture both one-time news events, such as assassinations, protests, and invasions, as well as events that unfold over weeks or even months, such as border disputes, reparations and debt negotiations, and declining state capacity. The latter appear in the data as sequential months with high RV.

In the sub-sections that follow, we document these two features of the relationship between the highest RV months and news for the GAPH countries, which are characterized by persistently high levels of uncertainty throughout their sample periods. Recent scholarship suggests that high-volatility regimes are particularly relevant for capturing uncertainty's impact on macroeconomic outcomes. For example, Danielsson et al. (2016) find that large deviations from standard conditions of financial market volatility, both positive and negative, contribute to the incidence of banking and financial crises in the near future. Jurado et al. (2015), using a broader measure of macroeconomic uncertainty, find that large positive innovations due to uncertainty led to sizable declines in real activity in post-WWII U.S. data; notably, macroeconomic uncertainty shocks accounted for ten times more of their 12-monthahead forecast error variance than policy rate shocks and twice as much as stock market

\footnotetext{
${ }^{19}$ Appendix Table 1 displays the five months with the largest realized volatility for non-hyperinflationary countries in our sample.

${ }^{20}$ Although we cannot rule out that we missed market-moving news, a corollary is that non-policy news does not appear to be correlated with high RV months; i.e., the majority of months with high RV values have corresponding news items with economic policy implications.
} 
volatility. Accordingly, we show in this section that our RV series based on exchange-rate volatility provide reasonable proxies for national economic uncertainty, and thus can be used in our subsequent analysis of inflation and macroeconomic dynamics during the interwar period.

\section{IVA. Austria}

The Treaty of Saint Germain was signed in September 1919 and established the first Austrian republic. ${ }^{21}$ As noted earlier, the treaty reduced the size of Austria, handing over former parts of the empire to existing and newly-formed states; obligated Austria to pay reparations while not specifying the amount or payment schedule; and prohibited Austria from re-uniting with either Germany or Hungary. The new Austrian republic struggled to formulate a stable government, first relying on the temporary government of the Social Democrat Karl Renner, and then inviting the former emperor to return to create a constitution. On December 25, 1919, Karl IV was crowned Archduke of Austria, but food and raw material shortages continued into the winter, fueling labor unrest and putting pressure on the government to provide relief. During the winter of that year, the Allies pushed Austria to disarm, but it refused to do so, given the uncertainty over its borders. As a consequence, military spending remained elevated. In January 1920, news reports cited continued economic dislocation in the country: Vienna had run out of coal and was shutting down its electric tram system.

The fledgling government was unable to formulate a budget plan in 1920. Each successive draft of the budget (the $4^{\text {th }}$ of the year in May) showed a growing deficit. In May, protests erupted over a proposed tax on capital erupted. By January 1921, the government declared itself insolvent and turned its finances over to the Reparations Commission. Revenue could not keep pace with expenditure, and the deficit had expanded from \$2.7 million paper crowns for fiscal year 1919-20 to \$41.1 million paper crowns for fiscal year 1920-21.

Two border crises also boiled over in 1920 creating additional uncertainty and additional budgetary demands. First, Tyrol and Salzburg held plebiscites in May, voting to breakaway and join Germany; this provoked strong responses from Italy and France, complicating Austria's ability to get them to release reparation liens. Second, Hungary seized Burgenland in September 1920, a region promised to Austria in the Treaty of St. Germain. An

\footnotetext{
${ }^{21}$ New York trading in the Austrian currency began in July 1919, as reported in the Commercial \& Financial Chronicle.
} 
armed struggle continued through December 1921 when a plebiscite, organized with Italian diplomatic assistance, resulted in placing most of the region within Austria.

In the first half of 1921, Austria sought a loan to stabilize its financial situation, pledging revenues from customs, the state railway, and salt and tobacco monopolies. The idea was eventually endorsed in July by the League of Nations. However, the loan could only be offered if other countries were willing to remove their liens on the Austrian assets that were pledged as part of the reparations agreement, which they refused to do. In August 1922, Lloyd George stated that the Allied governments were unable to extend further financial assistance to Austria unless guarantees of reconstruction were made by the League of Nations. In October 1922, under the auspices of the League of Nations, protocols signed with foreign powers for an economic reconstruction were signed by Austria.

\section{IVB. Germany}

As displayed in Figures 3 and 4, the RV series for Germany is quite elevated and reached extraordinary levels, reflecting the frequent and severe political and economic crises that roiled the country in the wake of World War I. Problems arose immediately following Germany's decision to accept the Versailles Treaty in January 1920. On March 13, a general strike was called in Berlin to protest Germany's decision to abide by the terms of the treaty, in particular the payment of reparations. On that same day, monarchists staged the Kapp Putsch and drove Gustav Bauer's republican government from the nation's capital, forcing it to flee to Stuttgart. A day later, amidst the chaos in the capital, communists seized the demilitarized regions of the Ruhr, initially in response to the Kapp Putsch, but also with designs to gain control of the republic. Roughly 300 policemen were killed. Both uprisings were quashed by the end of the month, but not without considerable bloodshed, especially in the Ruhr, as well as the fall of the government, with Bauer's resignation on March $27^{\text {th }}$.

Meanwhile, operating under the new constitution of August 1919, the government redirected control of state finances away from local and regional governments by passing a law that prohibited these jurisdictions from imposing any taxes that were similar in origin to those of the federal government. A federal tax administration was established by the end of that year as were sources of taxation, including a turnover tax and a special levy on capital, the Reichsnotopfer (Graham, 1930, pp.36-7, 940). Although the London Ultimatum of May 1921 (which guaranteed payments of 132 billion gold marks) appeared to resolve the question of 
how much Germany would owe, after making only one payment, the new government, headed by Chancellor Joseph Wirth, requested a moratorium on reparations payments in December. This decision cast doubt over the future path of the nation's budget. In that same month, Germany's efforts to secure an international private bank loan to help finance its expenditures were rebuffed.

Germany requested a further delay in paying reparations after Foreign Minister Rathenau's assassination by extremists in June 1922, using the threat of default to exact a concession. In response, the Reparations Commission agreed to a six-month moratorium on payments, in part because the politically delicate transfer of Upper Silesia to Poland was taking place simultaneously. With the Reichstag protesting new taxes to fund reparations payments, by August 1922, new French Prime Minister Raymond Poincare was demanding payment of reparations and threatening "coercive measures," presumably occupation of the Ruhr, if they were not paid. By October, Wirth had requested a full moratorium on debt payments, but the French position had hardened such that it refused to pay its Allied war debts until it received reparations from Germany. The German request for a moratorium was not met. Chancellor Wirth was compelled to resign in November 1922 after the Social Democrats resisted his attempt to broaden the ruling coalition to include the German People's Party. At the same time, capital flight was worsening, and Germany responded by imposing exchanged controls. A second London conference aimed at resolving the reparations impasse ended in December 1922 with no new agreement, and the Reparations Committee warned Germany it was in default over its failure to deliver timber to France.

When Germany missed its reparations-related delivery of coal in January 1923, the RC declared the country in technical default. In response, Belgium and France invaded the Ruhr Valley with more than 60,000 troops, an event which came to dominate the German domestic political dialogue. Germany responded by ordering government employees to disobey the occupying French. German banks closed in Dusseldorf in response to occupation, and a broad strike in the mines led to the French arrest of the German heads of these operations. Toward the end of the month and into the next, France tightened its control over the Ruhr and barred exports from the region to non-occupied Germany. The Ruhr dispute continued throughout the spring, with the German government financing "passive resistance" to French occupation, further straining its budget. In June 1923, France and Belgium called for an end of German passive resistance in the Ruhr as a quid pro quo for a new reparations conference; they occupied 
Dortmund, leaving only one railway line out of the Ruhr. By November, Chancellor Stresemann had resigned after a vote of non-confidence, and the hyperinflation reached its peak. The new central bank - the Rentenbank - and its gold-indexed rentenmark were introduced in October.

\section{IVC. Hungary}

Hungary began its postwar existence as a weakened state with limited capacity. It eventually repelled the Czechoslovak and Romanian incursions of 1919 and signed a peace treaty in June 1920. It withstood a five-month period with communist leadership, but emerged from this turbulent period behind the authoritarian leadership of Admiral Miklos Horthy, who was appointed by the assembly as the kingdom's regent (the Allies were unwilling to allow a monarch to govern Hungary) and who turned his immediate attention to lynching the supporters of a Soviet Hungary ("the white terror"). In the second half of the 1920, the appointed Prime Minister Teleki had to form two consecutive governments to maintain power, put down wayward military units in Budapest, and convince a reluctant National Assembly to ratify the Treaty of Trianon, which it finally did in November. Rumors of a coup by former emperor Charles IV threatened the government's existence in early 1921 as did a continuing territorial dispute with Austria over the Burgenland region. The coup by Charles IV finally materialized in March; however, without military support, he was forced to retreat to western Hungary.

By September, the border dispute with Austria intensified, when Hungary sent troops into the region to protect its access to railway lines. The Allies warned Hungary to withdraw. Meanwhile, Finance Minister Lorant Hegedus resigned in September 1921 as the budget situation worsened. Political instability continued to plague the young republic in the second half of the year, with Charles IV attempting another coup and the National Assembly responding to his attempt by passing the Dethronement Act of the House of Habsburg in November. In December, the city of Sopron, a German-speaking area within Burgenland, held a plebiscite and voted to remain with Hungary despite Austria's treaty-based territorial claim.

At the end of 1921, the country appointed yet another minister of finance (Tibor Kallay); the government continued to operate under a provisional budget since it had failed to pass a budget bill for the fiscal year. Finance minister Hegedus claimed the budget deficit amounted to $\$ 6$ billion kronen (paper crowns), but the situation was clearly much worse. By 
January 1922, the government announced a deficit double its previous estimate, and used the provisional budget to authorize the payment of both the capital and interest on the public debt using bond finance. For fiscal year 1922-23, the deficit reached $\$ 40.7$ billion. ${ }^{22}$ Hungary's continued aggression toward the newly-formed central European states, prompted Czechoslovakia, Romania and the Kingdom of Serbs, Croats and Slovene (Yugoslavia) to form the Little Entente - treaties negotiated in 1922 and finalized in August, which recognized each other's independence and promised mutual defense against Hungary. In September, with the budget and capital flight worsening, Hungary implemented foreign exchange controls and requested admittance to the League of Nations in the hopes of obtaining a loan to stabilize the economic situation.

\section{IVD. Poland}

Facing five territorial disputes (two with Czechoslovakia, and one each with Germany, Lithuania, and Russia), Poland's postwar existence was highly uncertain. Its RV measure often changed in response to events associated with these disputes and the war with Russia. After its surrender, Germany withdrew its armies from the Eastern front, leaving a power vacuum that was quickly filled by the Russians and Poles, both of whom laid claim to the area spanning parts of present-day Latvia and the area in present-day Ukraine between Kieve and Lviv. The territorial dispute escalated into warfare, with both countries claiming historical precedent to these areas. While each side in the conflict had seen some success in their offensives in the first half of 1920, Russia was forced to sue for peace in November and negotiations began the following month; however, labor strikes arose in Polish occupied parts of former Russian territory. At the same time, Polish relations with Lithuania rapidly deteriorated when general Zeligowski set up a permanent occupation force in Vilnius over strong objections from Lithuania. An attempt by Belgium to settle the dispute between Lithuania and Poland failed in December.

Facing budget pressures from these disputes, Treasury Minister Grabsky resigned. Negotiations with Russia dragged on into early 1921, and food and clothing shortages worsened in the big cities of Poland. Multiple uprisings among the Polish population in Upper Silesia occurred in 1921, with hostilities spiking in August, and the Supreme Council of the Allies ordered a cessation to fighting as they worked to resolve this territorial dispute. The

${ }^{22}$ The Statesman's Year-book: Statistical and Historical Annual of the World for the Year 1925 (1925, p.686). 
budget minister of Poland requested strict supervision of all expenditures by the Diet, including military spending, as the fiscal position of the country eroded further.

The League of Nations resolved the German border dispute over Silesia in October 1921, with Poland receiving most of the industrial areas but only about one-third of the contested land. However, it made no headway on Poland's dispute with Lithuania. In February 1923, the League relented and simply divided the neutral zone - setting a demarcation line as the official border, but one which Lithuania refused to recognize. The dispute thus remained unresolved during our sample period.

In June 1923, the Sikorski government was overthrown, and a new Cabinet led by Witos of the Piast (Peasant) party took charge. He kept Grabsky on as minister of treasury, who intended to introduce currency reform (zloty), balance the budget, and lower inflation. However, Witos then decided not to support these reforms, and Grabsky resigned in protest the following month. Witos and Linde, his new finance minister, attempted to secure a foreign loan of $\$ 100$ million loan from Hallgarten \& Co. as well as a \$150 million loan from J.P. Morgan to finance budget deficits, but both attempts failed. Poland was given official notice of the creation of USSR in that same month.

\section{Estimating the Role of Uncertainty on Macroeconomic Outcomes in the 1920s}

The preceding sections summarize how Europe found itself in a highly uncertain environment after World War I, and that economic policy uncertainty - as measured by the realized volatility in exchange rates - was particularly pronounced in countries that ultimately experienced hyperinflations. The detailed examination of GAPH in Section 4 (and the other countries in Appendix Table 1) further suggests that RV months are associated with events or news that could influence the course and direction of fiscal policy. We now consider whether the RV measure provides insight into inflation dynamics.

As shown in Table 4, there are several constraints that define our sample period and coverage. First, we are limited by data availability for the ten European countries in the sample. For example, the earliest month for which we have sufficient data to conduct our multivariate analysis discussed below is July 1919, when the daily exchange rate series are first reported for the UK, the Netherlands, and Italy. Another constraint concerns the availability of monthly inflation figures, which are available in the early 1920s for GAPH as well as for Belgium, 
Czechoslovakia, and the Netherlands. The last column of Table 4 lists the number of monthly observations available for each country.

In terms of measuring the relationship between uncertainty and inflation, one necessary modeling assumption is deciding on when hyperinflation began for the countries that experienced it. Our intuition is that when a country crosses over into a state of hyperinflation, the stability of the macroeconomic relationships that we would hope to capture with a model break down sufficiently as to prevent reasonable inference and would quite likely provide spurious inference. Because there is no standard definition of hyperinflation, we use the simple rule of a $100 \%$ change in monthly prices within a month (i.e., a doubling of the level of prices) to define the onset of hyperinflation within a country. Thus, as shown in the top panel of Table 4, our sample period for Germany ends in June 1923, with a monthly inflation rate of about $86 \%$, since the inflation rate in the following month was $136 \% .{ }^{23}$ Similarly, our end date for Poland is September 1923, when the monthly inflation rate was $32 \%$, since inflation reached $132 \%$ in the following month.

Due to external intervention, the start of hyperinflation for Austria and Hungary are defined somewhat differently. For the Austrian sample, the monthly inflation rate reaches a maximum of only $83 \%$ in August 1922. In the following month, the League of Nations extended the country a significant loan and assumed control of certain monetary functions. As this represented a regime shift and effectively ended trading in the kronen (i.e., no reported price fluctuations in New York trading), our RV measure of uncertainty could not be calculated beyond September 1922. For Hungary, monthly inflation rates were certainly elevated, reaching 68\% in July 1923 and 52\% in February 1924, but never exceeded 100\%. However, Sargent (1982) describes Hungary as experiencing hyperinflation by noting that its price index increased by a factor of 263 between January 1922 and April 1924. Accordingly, we also use regime change to mark the sample's endpoint at June 1924 - when the Hungarian National Bank was formed and the krone effectively stopped trading before the forint was introduced in August 1924.

\footnotetext{
${ }^{23}$ The hyperinflation reached a peak of a monthly inflation rate of $569 \%$ in October 1923 before the reichsmark was decommissioned and replaced in December 1923; see Webb (1986). Salemi (1980) chose the same endpoint of June 1923 for his study based on judgment; i.e., he stated that "a regression attempting to explain [German inflation] between February 1921 and August 1923 might do well by explaining [German inflation] for only the last few months."
} 
Before describing our econometric approach, Table 5 presents simple summary statistics on the correlations between the monthly changes in countries' inflation rates (denoted as $\Delta \pi_{\mathrm{k}, \mathrm{t}}$ ) with lagged values of the changes in their RV values; i.e.,

$$
\rho\left(\Delta \pi_{\mathrm{kt}}, \Delta \mathrm{RV} \mathrm{kt}_{\mathrm{j}}\right), \mathrm{j} \in[0,6]
$$

These correlations provide a simple view into how changes in uncertainty influence future changes in inflation. The top panel presents the correlations for GAPH. The first point to notice is that, with the exception of Poland, there is a fairly large contemporaneous correlation between changes in GAPH uncertainty and inflation, ranging from 0.25 to 0.38 ; i.e., inflation and uncertainty tended to move together in these countries. Although the correlations are calculated over the relatively short sample periods available, we still observe that these values are positive, relatively large, and statistically significant at the $15 \%$ level. The second point to notice is that the one-lag correlations remain positive and significant for all GAPH countries except Austria, whose second-lag correlation fits this pattern. These correlation patterns provide intuitive support for the hypothesis that economic uncertainty is an important driver of inflation in countries experiencing hyperinflation.

The correlations shown in the bottom panel of Table 5 suggest a different result for the other countries in the sample. Britain, Czechoslovakia, and France show barely any correlation at any lag between these two variables. The contemporaneous correlations for Belgium, the Netherlands, and Italy are similar to those of the GAPH countries in magnitude and significance, but their subsequent lagged correlations oscillate in a pattern that likely negates the initial contemporaneous correlations. Overall, these correlation patterns provide preliminary support for the hypothesis that uncertainty, as reflected in our RV measures, was not likely pronounced enough in these countries to influence their inflation dynamics and certainly not to induce hyperinflation. ${ }^{24}$

To estimate more fully the effects that uncertainty had on the economic dynamics of European economies after World War I, and inflation in particular, we frame our analysis in terms of a, reduced-form macroeconomic model that is similar to a vector autoregression (VAR). That is, for each country in our sample, we introduce our RV series into a small modeling system that includes changes in inflation $(\Delta \pi)$, industrial production $(\Delta \mathrm{IP})$, and notes

\footnotetext{
${ }^{24}$ The results of formal Granger-causality testing of the bivariate relationship between the countries' uncertainty and inflation series are available upon request.
} 
(or money) in circulation ( $\Delta$ Notes) at a monthly frequency. The latter variable has been highlighted as a way of gauging fiscal policy regimes (Frankel, 1980; Sargent, 1982; and Webb, 1986). As government expenditures fluctuated due to volatile tax revenues, reparations negotiations, and military actions, different countries were, to varying degrees, financing deficits through the issuance of debt obligations or by monetizing them. The latter is clearly a precursor to rising inflation and loss of currency value. Thus, the growth of notes in circulation, particularly for the GAPH countries, is an important variable in our empirical framework. ${ }^{25}$ As per Leduc and Liu (2015), the model places contemporaneous and lagged values of the RV series first in order, such that uncertainty does not respond to macroeconomic shocks in the current period, while the other series can change based on an uncertainty shock. The macroeconomic data were hand collected from government documents and League of Nations publications as described in the Appendix.

While VAR models are standard tools for assessing macroeconomic dynamics, they are subject to certain general challenges as well as some specific challenges. As summarized in recent work by Barnichon and Brownlees (2017), VARs provide meaningful dynamic structure and shock identification to the system of variables under analysis, which translates into efficient parameter estimation and generation of multipliers of interest, such as impulse response functions (IRFs). However, inference drawn from VARs is highly dependent on the chosen model specification and is not robust to model misspecification. In response to this shortcoming, Jòrda (2005) proposed computing IRFs based on local projections (LP), which are a sequence of predictive regressions of a variable of interest on a structural shock over different horizons. Using the LP approach, to generate an IRF over the period from $\mathrm{T}$ to $\mathrm{T}+\mathrm{j}$, one would run $\mathrm{J}$ regressions with the same explanatory variables and a dependent variable whose time index increments from $\mathrm{T}$ to $\mathrm{T}+\mathrm{j}$. The IRF is then simply the sequence of regression coefficients on the structural shock parameter. The same logic holds for the estimated confidence bands. This technique is more robust to possible misspecification and does not suffer from the curse of parameter dimensionality inherent to VARs. These properties are of particular value in our study, which has limited sample size and thus requires as much estimation parsimony as possible.

${ }^{25}$ Our macroeconomic series are constructed from various relevant historical references; see the Appendix for details. 
The LP methodology nevertheless still requires a large number of estimated parameters and has been found to be excessively noisy under certain circumstances (Ramey, 2016). In a recent paper, Barnichon and Brownlees (2017) propose an LP estimator that improves on both of these considerations by imposing the restriction that an IRF be a smooth function across the horizon of interest. This restriction, as well as the shrinkage estimation technique employed, reduces the number of estimated parameters, and provides clearer inference between variables across the horizon of interest. Given that our sample contains between 20 and 66 monthly observations, depending on the particular country, this smooth local projection (SLP) estimator provides overwhelming benefits in terms of parameter estimation, IRF generation, and meaningful inference relative to other estimators. Correspondingly, the results from our SLP regressions form the basis of our empirical analysis. The SLP regressions we estimate are:

$$
\Delta \pi_{\mathrm{kt}+\mathrm{j}}=\alpha_{\mathrm{kj}}+\beta_{1 \mathrm{kj}} \Delta \mathrm{R} V_{\mathrm{kt}}+\beta_{2 \mathrm{kj}} \Delta \mathrm{RV} \mathrm{kt}_{\mathrm{k}}+\beta_{3 \mathrm{kj}} \Delta \pi_{\mathrm{kt}-1}+\beta_{4 \mathrm{kj}} \Delta \mathrm{IP}_{\mathrm{kt}-1}+\beta_{2 \mathrm{kj}} \Delta \text { Noteskt-1 }_{\mathrm{k}}+\varepsilon_{\mathrm{kt}+\mathrm{j}}
$$

where $\Delta$ represents the log first difference of the series.

Figure 5 presents SLP-generated IRFs for GAPH, for the effect of a unit (or onestandard deviation) increase in uncertainty on the monthly inflation rate. ${ }^{26}$ The IRFs exhibit a common downward trend from above zero at the start of the projection horizon to below zero by the sixth month. This general pattern supports the hypothesis that an increase in uncertainty corresponds to an increase in inflation in the contemporaneous month and the month immediately following, although the effect declines to zero by the third month and either remains there or reverses in subsequent months. Importantly, the SLP-generated confidence bands (plotted at the 95\% level) show that these positive relationships are statistically significant in GAPH for the contemporaneous month and the first month of the projection. Thus, our empirical results support the view that uncertainty shocks lead to an immediate, if relatively short-lived, increase in inflation. Of course, for some countries in our sample, such shocks occur with high frequency, so uncertainty may cumulate to have a large effect on the inflation rate.

The magnitudes of the effects of uncertainty on contemporaneous inflation are summarized in Table 6. As shown in the first row, the standard deviation of log changes in the monthly German RV measure is 1.21 , which is equivalent to an increase of $235 \%$ in RV value.

${ }^{26}$ Tables of the estimated, country-level SLP coefficients are available upon request. 
The model-implied response of the monthly log growth rate of inflation for Germany is 0.139 , which is an increase of 0.17 standard deviations or, equivalently, a $7.9 \%$ inflation increase. Table 7 shows the effect for the first month of the project horizon. As shown in the first row, a one-standard-deviation increase in Germany's RV measure in month $\mathrm{t}$ leads to an increase in the inflation rate in month $\mathrm{t}+1$ of 0.03 standard deviations, which corresponds to an increase of $3.3 \%$ in value. As shown in Figure 5, after two months, the cumulative effect was zero. Thus, a one-standard-deviation increase in uncertainty translates into a cumulative 11.2 percentage-point increase in Germany's monthly inflation rate.

As shown in Figure 5, the SLP impulse response functions for Austria, Poland, and Hungary exhibit similar patterns of positive and significant responses early in the projection horizon, and then decline to nearly zero by the third month. As Table 6 shows, the estimated contemporaneous coefficient for Austria means that a one-standard-deviation shock to uncertainty leads to an increase in the monthly inflation rate of 17 percentage points. If we then add the one-month-lagged effect, recorded in Table 7 as a 9.7 percentage point increase, the empirical results suggest that Austrian inflation would rise by 26.7 percentage points after a one-standard-deviation increase in uncertainty.

The contemporaneous effects for one-standard-deviation increases in uncertainty for Poland and Hungary result in inflation rates that are roughly 8 and 15 percentage points higher, respectively. Incorporating the one-month lagged response, results in monthly inflation rates that are 12.8 and 30.3 percentage points higher, respectively. These results strongly suggest that uncertainty played an important role in determining inflation dynamics during the interwar period for countries that subsequently experienced hyperinflations.

In contrast, Figure 6 shows the more limited role that uncertainty played in the inflation dynamics of the other European countries; i.e., the IRFs are essentially flat at or oscillating slightly near zero. The estimated responses are not statistically significantly different from zero at the $10 \%$ level in almost all cases The magnitudes of these estimated responses are also notably smaller, ranging between -0.01 and +0.01 at the contemporaneous and one-month horizons. As shown in Tables 6 and 7, the marginal effects of an increase of one-standarddeviation change in the RV measure on the inflation rate are quite small for the nonhyperinflation countries, with effects less than a $1 \%$ change in absolute value. For example, in the cases of Britain and the Netherlands, the cumulative two-month effect of a one standard- 
deviation in the logged change in the national RV measure on monthly inflation are -0.5 and +1.2 percentage points, which are an order of magnitude smaller than for GAPH.

Czechoslovakia's SLP results are particularly interesting to compare to GAPH. As Figure 6 shows, inflation in Czechoslovakia initially responds to increased uncertainty by declining. The contemporaneous and one-period-ahead projections shown in Tables 6 and 7 are negative, though not both statistically significant, and cumulate to a decline of nearly 2 percentage points. So why are the effects of uncertainty for Czechoslovakia's inflation rate different in sign and size from GAPH when its RV was roughly equal to Germany's and Hungary's in 1920? After all, it too had border disputes, imperial legacy debts, and new institutions - all conditions that more than likely contributed to another newly-created country's (i.e., Poland's) high measured uncertainty and eventual experience with hyperinflation.

The likely reason appears in 1922, and as shown in Figure 2; that is, Czechoslovakia's policy uncertainty declined dramatically. Under the leadership of finance minister Alois Rasin, the country first committed to obtaining a stable currency in 1919, shortly after it gained its independence (Sargent, 1982). Czechoslovakia then eventually adopted a fixed exchange rate by going onto the gold standard. As emphasized by Kydland and Prescott (1977), a hard peg, like Czechoslovakia adopted, tied the hands of the monetary and fiscal authorities and committed the policymakers to following rules. This decision no doubt helped to reduce uncertainty about the future path of policy. Czechoslovakia's policy making was then consistent with its hard peg: it implemented a capital levy to move the budget toward balance, as Germany did, but it was able to do so without the additional uncertainty over reparations payments that saddled Germany. Finally, it faced border disputes, just as Poland did, but it did not engage in a drawn out war, as Poland did with Russia. Rather, it was able to neutralize its most serious external threat, Hungary, by entering into the Little Entente in August 1922 - a date consistent with when we see the Czechoslovakia's RV begin to decline (Figure 2).

\section{Conclusion}

The physical and political destruction wrought by the First World War traumatized Europe and had economic reverberations long after the official peace treaties were signed. Both the victors and the vanquished faced massive costs of reconstruction, uncertainty regarding political borders and tax revenues, and extended negotiations over war reparations. 
Europe thus faced an environment of heightened uncertainty that deeply affected economic expectations and outcomes.

We develop a methodology that utilizes country-specific events to show how uncertainty was a key driver of the inflation dynamics for Germany, Austria, Poland, and Hungary, but not for other European countries after World War I. It allows us to show how uncertainty over reparations increased policy uncertainty in both France (as a receiver) and Germany (as a payer). However, the effects of this uncertainty were significantly greater for Germany and likely drove inflation expectations in that country into a negative spiral, as detailed by historians (Webb, 1986). More generally, our methodology provides insight into why hyperinflation emerges in some countries but not others. In the context of World War I, pronounced economic policy uncertainty took the form of uncertainty over country borders, legacy debts, and reparation payments. Adopting nominal anchors (such as the gold standard) becomes more difficult to implement in highly uncertain environments such as these since policymakers are challenged in convincing households, business, and financial markets that there policies are credible.

For our analysis, we examine the relationship between uncertainty and inflation dynamics within an economy. Our results show that in a period of heightened general uncertainty, such as the interwar period, higher relative levels of uncertainty were significant drivers of inflation dynamics for the countries that subsequently experienced hyperinflation. In contrast, lower relative levels of uncertainty in other European countries did not influence their inflation dynamics. These joint empirical results align well with recent work by Vavra (2014), who shows how heightened economic uncertainty differentially influences the price setting mechanism, monetary policy, and output growth. The results are also in line with the finding by Danielsson et al. (2016)' i.e., periods of unusually high and low uncertainty are more meaningful indicators of financial stability (i.e., banking crises in their work) than just the level value of uncertainty itself. Our results support the view that heightened economic uncertainty - both in relative terms within a country and across countries - contributed to the macroeconomic and price dynamics that led to rising levels of inflation in the countries that tipped into hyperinflation.

Finally, our findings relate to the work of Cole and Kehoe $(1996,2000)$ who show that financial crises that threaten a country's ability to repay its debt may quickly become self-fulfilling, and lead to a debt crisis. The parallel to fiscal policy and inflation expectations 
in the interwar period is clear. If economic agents believed that GAPH debts could not be repaid as long as budget discipline was non-existent, then tipping into hyperinflation becomes self-fulfilling. Further analysis of the fiscal conditions of these countries at the monthly level and their relationships with our uncertainty measure should be a fruitful direction for future work. 


\section{REFERENCES}

Andersen, T., Bollerslev, T., Diebold, F.X., and Labys, P., 2003. "Modeling and Forecasting Realized Volatility," Econometrica, 71, 579-625.

Baker, S.R. and Bloom, N., 2013. "Does Uncertainty Reduce Growth? Using Disasters as Natural Experiments.” NBER Working Paper 19475.

Baker, S.R., Bloom, N., and Davis, S.J., 2016. "Measuring Economic Policy Uncertainty," Quarterly Journal of Economics, 131, 1593-1636.

Balderston, T., 1989. "War Finance and Inflation in Britain and Germany, 1914-1918," Economic History Review 42(2): 222-44.

Baillie, R., Bollerslev, T. and Redfrearn, M.R., 1993. "Bear Squeezes, Volatility Spillovers and Speculative Attacks in the Hyperinflation 1920's Foreign Exchange, Journal of International Money and Finance, 12, 511-521.

Barnichon, R. and Brownlees, C., 2017. "Impulse Response Estimation by Smooth Local Projections," Manuscript, Federal Reserve Bank of San Francisco.

Bianchi, F. and Melosi, L., 2017. "Escaping the Great Recession," American Economic Review, 107, 1030-1058.

Bloom, N., 2009. “The Impact of Uncertainty Shocks,” Econometrica, 77, 623-685.

Boemeke, Manfred F., Gerald D. Feldman, Gerald D. and Elisabeth Glaser (editors). 1998. Versailles: A Reassessment after 75 Years. Cambridge University Press.

Bogart, E.L. .1920. Direct and Indirect Costs of the Great World War. New York: Oxford University Press.

Bordo, M.D. and MacDonald, R., 2003. "The Interwar Gold Exchange Standard: Credibility and Monetary Independence," Journal of International Money and Finance, 22, 1-32.

Bordo, M.D. and Siklos, P.L., 2014. "Central Bank Credibility, Reputation and Inflation Targeting in Historical Perspective,” NBER Working Paper \#20693.

Bordo, M.D. and Siklos, P.L., 2015. "Central Bank Credibility: An Historical and Quantitative Exploration,” NBER Working Paper \#20824.

Broadberry, S. and Harrison, M., 2005. "Introduction," The Economics of World War. Cambridge: Cambridge University Press, pp. 3-40.

Cagan, P., 1956. “The Monetary Dynamics of Hyperinflation” in Friedman, M. (ed.), Studies in the Quantity Theory of Money. Chicago: University of Chicago Press. 
Caggiano, G., Castelnuovo, E. and Groshenny, N., 2014. "Uncertainty Shocks and Unemployment Dynamics in U.S. Recessions," Journal of Monetary Economics, 6778-92.

Carriero, A., Clark, T.E., and Marcellino, M., 2018. "Endogenous Uncertainty,” Federal Reserve Bank of Cleveland Working Paper \#2018-05

Cole, H.L. and Kehoe, T.J., 1996. “A Self-Fulfilling Model of Mexico's 1994-1995 Debt Crisis," Journal of International Economics, 41, 309-330.

Cole, H.L. and Kehoe, T.J., 2000. “Self-Fulfilling Debt Crises,” Review of Economic Studies, 67, 91-116.

Commercial and Financial Chronicle (various years).

Danielsson, J., Valenzuela, M. and Zer, I., 2018. "Learning from History: Volatility and Financial Crises," Review of Financial Studies, forthcoming.

Davig, T. and Leeper, E.M., 2011. "Monetary-Fiscal Policy Interactions and Fiscal Stimulus.” European Economic Review, 55, 211-27.

Dornbusch, R., 1982. "Monetary Problems of Post-Communism: Lessons from the End of the Austro-Hungarian Empire," Weltwirtschaftliches Archiv, 128, 391-424.

Dumberry, P., 2007. State Succession to International Responsibility. Brill Publishing.

Durand, E D., 1922. "Public Finance of Poland." United States Department of Commerce, Supplement to Commerce Reports, Trade Information Bulletin No.32, Washington, D.C.

Eichengreen, B., 1992. Golden Fetters: The Gold Standard and the Great Depression, New York: Oxford University Press.

Einzig, P., 1937. The Theory of Forward Exchange. London: MacMillan.

Ferguson, Adam. 1975. When Money Dies: the Nightmare of the Weimar Collapse. London: William Kimber.

Fernández-Villaverde, J., Guerrón-Quintana, P., Kuester, K., and Rubio-Ramírez, J., 2015. "Fiscal Volatility Shocks and Economic Activity," American Economic Review, 105, 3352-3384.

Frankel, J.A., 1977. "The Forward Exchange Rate, Expectations, and the Demand for Money: The German Hyperinflation," American Economic Review, 67, 653-670.

Frankel, J.A., 1980. "The Forward Exchange Rate, Expectations, and the Demand for Money: The German Hyperinflation: Reply," American Economic Review, 70, 771775. 
Fraser, and Mark P. Taylor. 1990. "Modeling Risk in the Interwar Foreign Exchange Market," Scottish Journal of Political Economy, 37(3), 241-58.

Gilchrist, S., Sim, J.W., and Zakrajšek, E., 2014. "Uncertainty, Financial Frictions, and Investment Dynamics,” NBER Working Paper \#20038.

Graham, Frank D. 1930. Exchange, Pries, and Production in Hyperinflation: Germany, 1920-23. New York: Russell and Russell.

Jonas, Paul. 2016. "The Economic Consequences of Trianon," Hungarianhistory.com http://www.hungarianhistory.com/lib/tria/tria40.htm

Jurado, K., Ludvigson, S.C., and Ng, S., 2015. "Measuring Uncertainty," American Economic Review, 105, 1177-1216.

Kydland, Finn E., and Edward C. Prescott. 1977."Rules Rather than Discretion: The Inconsistency of Optimal Plans." Journal of Political Economy 85(3): 473-92.

League of Nations. 1937. Monetary Review, Money and Banking 1936/37, Volume 1, Geneva: League of Nations.

League of Nations. Monthly Bulletin of Statistics. Geneva: League of Nations.

League of Nations. 1938. Report on Exchange Control. Geneva: League of Nations.

League of Nations. various years. Yearbook. Geneva: League of Nations.

Leduc, S. and Liu, Z., 2016. "Uncertainty Shocks are Aggregate Demand Shocks," Journal of Monetary Economics, 55, 1113-1128.

Leeper, E.M., 2005. 'Equilibria under 'Active' and 'Passive' Monetary and Fiscal Policies.” Journal of Monetary Economics 27: 129-47.

Ludvigson, S., Ma, S., and Ng., S., 2018. "Uncertainty and Business Cycles: Exogenous Impulse or Endogenous Response?” Manuscript, Columbia University.

McCallum, Bennett T. and Edward Nelson. 2005. Oxford Review of Economic Policy 21(4), Fiscal Policy (Winter), 565-583.

Obstfeld, Maurice, Jay Shambaugh and Alan M. Taylor. 2004. "Monetary Sovereignty, Exchange Rates and Capital Controls: The Trilemma in the Interwar Period," IMF Staff Papers 51 (special issue).

Obstfeld, Maurice, and Rogoff, Kenneth. 1983. "Speculative hyperinflations in maximizing models: Can we rule them out? Journal of Political Economy 91 (August): 675-87. 
Paredes, J., Pérez, J.J., and Perez-Quiros, G. 2015. "Fiscal Targets: A Guide to Forecasters?" European Central Bank Working Paper \#1834.

Peel, D.A. and Spiru, A.M., 2015. "Consistency of Two Major Data Sources for Exchange Rates in the Interwar Period and Evidence on the Behavior of Exchange Rates during Hyperinflation: The Case of Germany," Manuscript, Lancaster University Management School.

Prochnik, Edgar L.G. 1922. "Possibilities of the Economic and Financial Reconstruction of Austria," The Annals of the American Academy of Political and Social Science, 102 (July), 20-26.

Ramey, Valarie. 2016. "Macroeconomic Shocks and their Propagation," Handbook of Macroeconomics, Volume 2A, 71-162.

Reinhart, Carmen M and Kenneth Rogoff. 2009. This Time is Different. Princeton University Press.

Ritschl, Albrecht and Tobias Straumann. 2010. "Business cycles and economic policy, 19141945.” In Stephen Broadberry and Kevin H. O'Rourke The Cambridge Economic History of Modern Europe, Volume 2, 1870 to the Present, pp.156-80.

Salemi, M.K. 1980. "The Forward Exchange Rate, Expectations, and the Demand for Money: The German Hyperinflation: Comment," American Economic Review, 70, 763-770.

Sargent, Thomas. 1982. "The Ends of Four Big Inflations” in Hall, R.E., ed. Inflation: Causes and Effects. Chicago: NBER, 41-98.

Statistiches Handbuch der Weltwirtschaft. various years. Verlag für Sozialpolitik, Wirtschaft und Statistik Paul Schmidt, Berlin.

Vavra, J., 2014. "Inflation Dynamics and Time-Varying Volatility: New Evidence and an S-s Interpretation," Quarterly Journal of Economics, 129, 215-258.

Webb, S.B. 1986. "Fiscal News and Inflationary Expectations in Germany after World War I," Journal of Economic History, 46, 769-794.

Woodford, M., 1995. "Price Level Determinacy without Control of a Monetary Aggregate," Carnegie-Rochester Conference Series on Public Policy, 43, 1-46.

Young, J.P, 1925. European Currency and Finance: Commission of the Gold and Silver Inquiry, United States Senate (Volumes 1 and 2). Washington, D.C., Government Printing Office. 
Figure 1. Realized volatility measures for the Netherlands and the UK

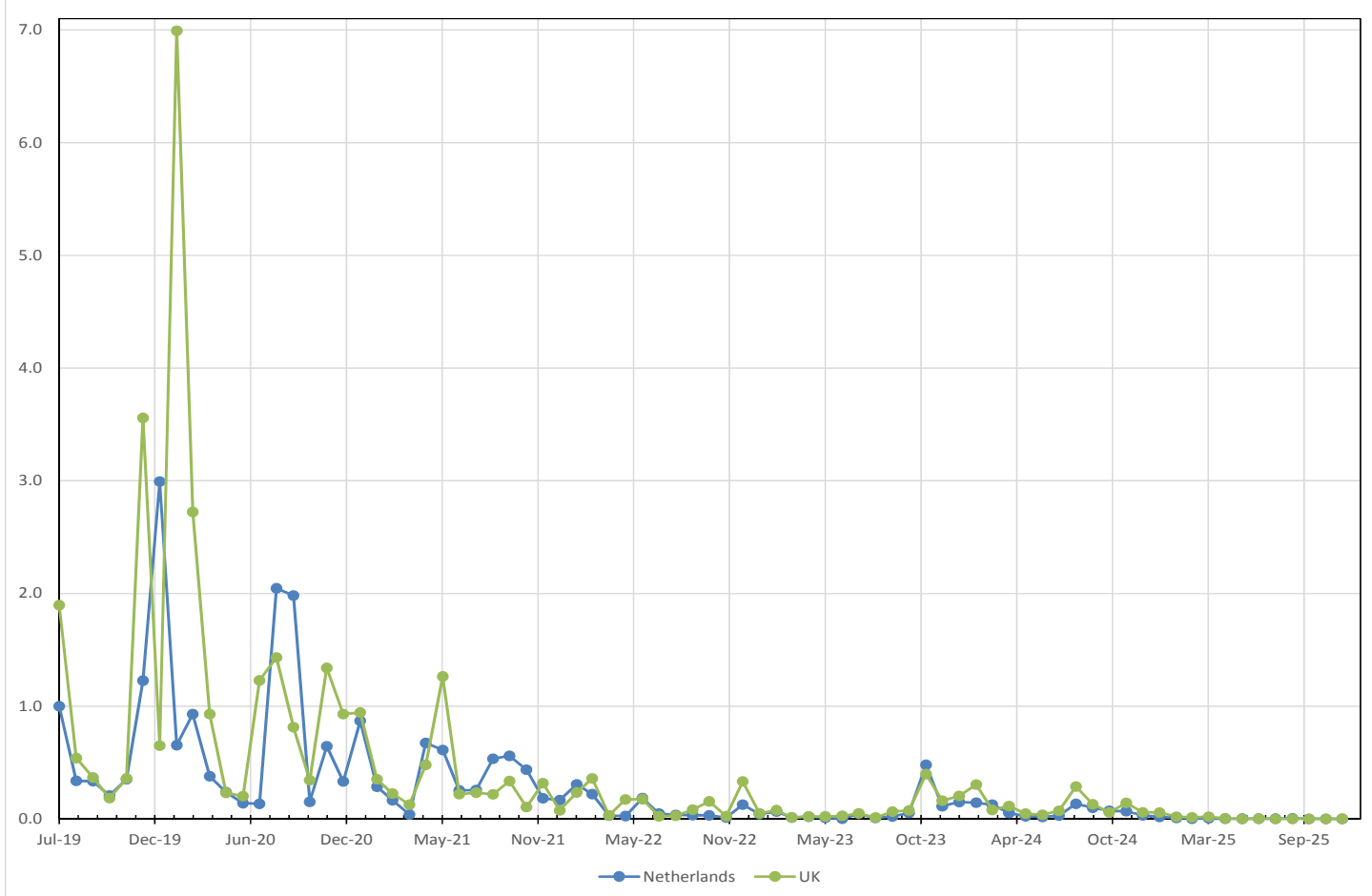

Note: Values are relative to the RV measure for the Netherlands in July 1919.

Figure 2. Realized volatility for the non-hyperinflationary European countries

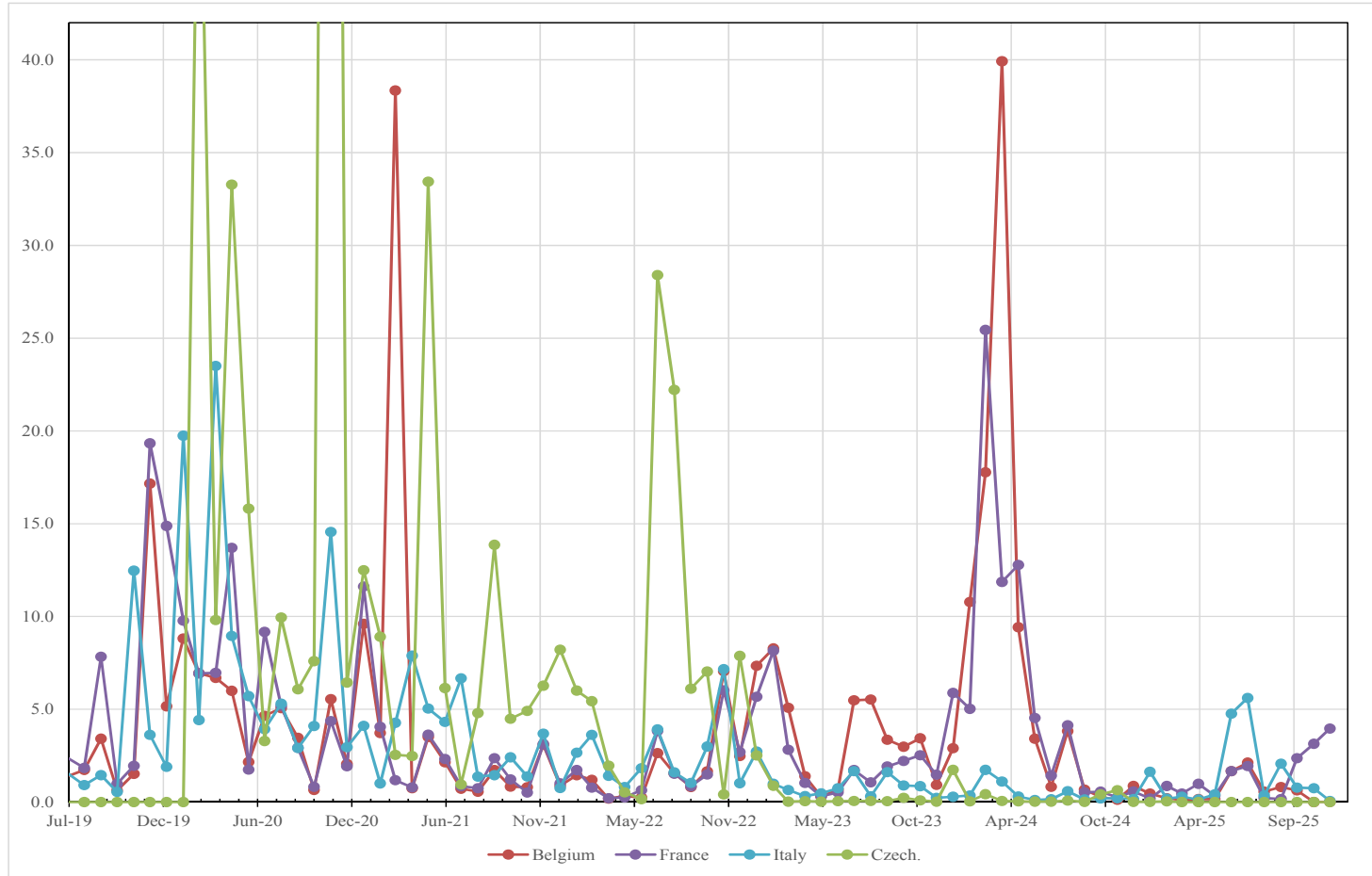

Note: Values for all countries are expressed relative to the RV measure for the Netherlands in July 1919. 
Figure 3. Realized Volatility for Germany

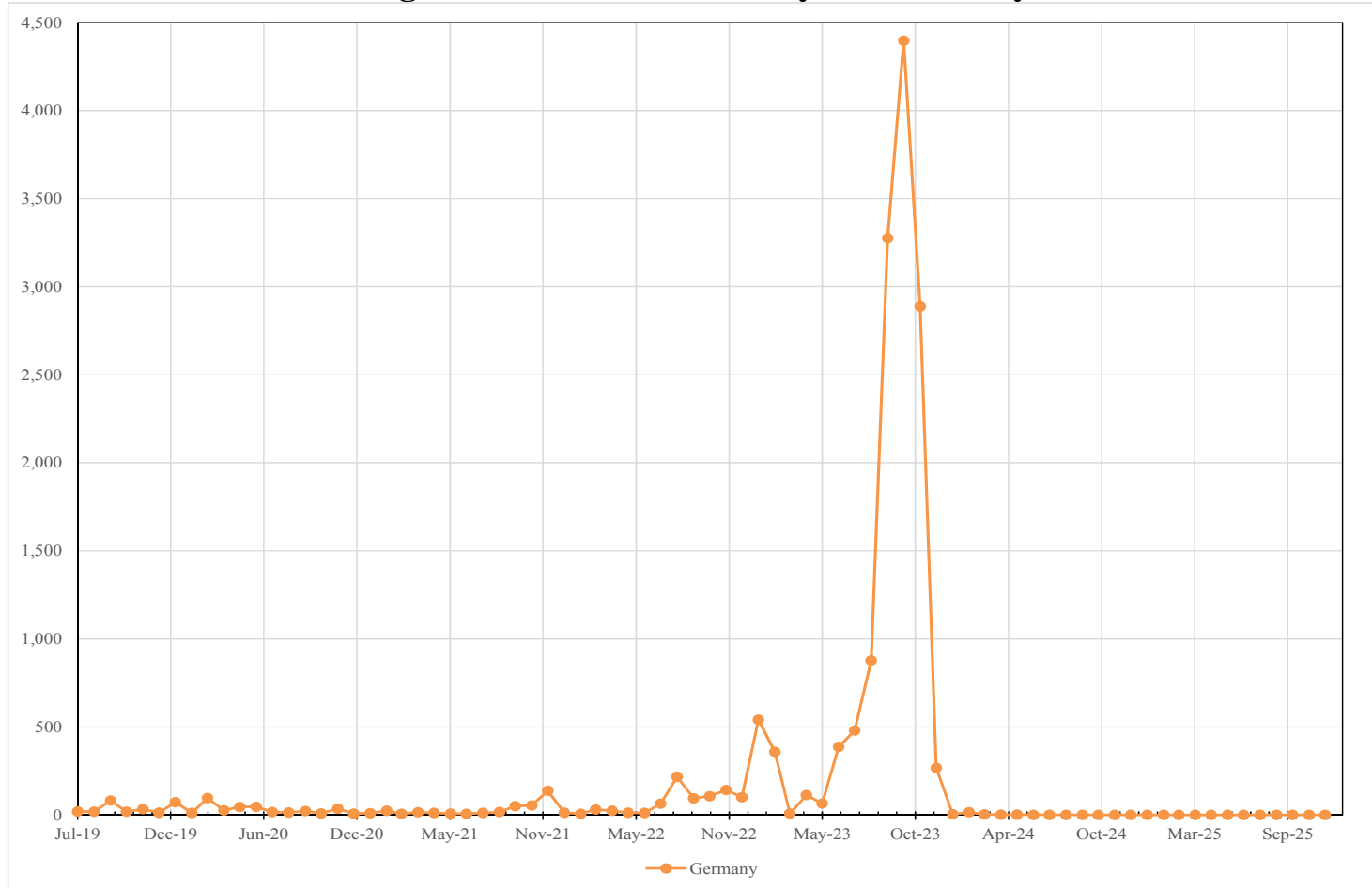

Note: Values for Germany are expressed relative to the RV measure for the Netherlands in July 1919.

Figure 4. Realized Volatility for Germany, Austria, Poland, and Hungary

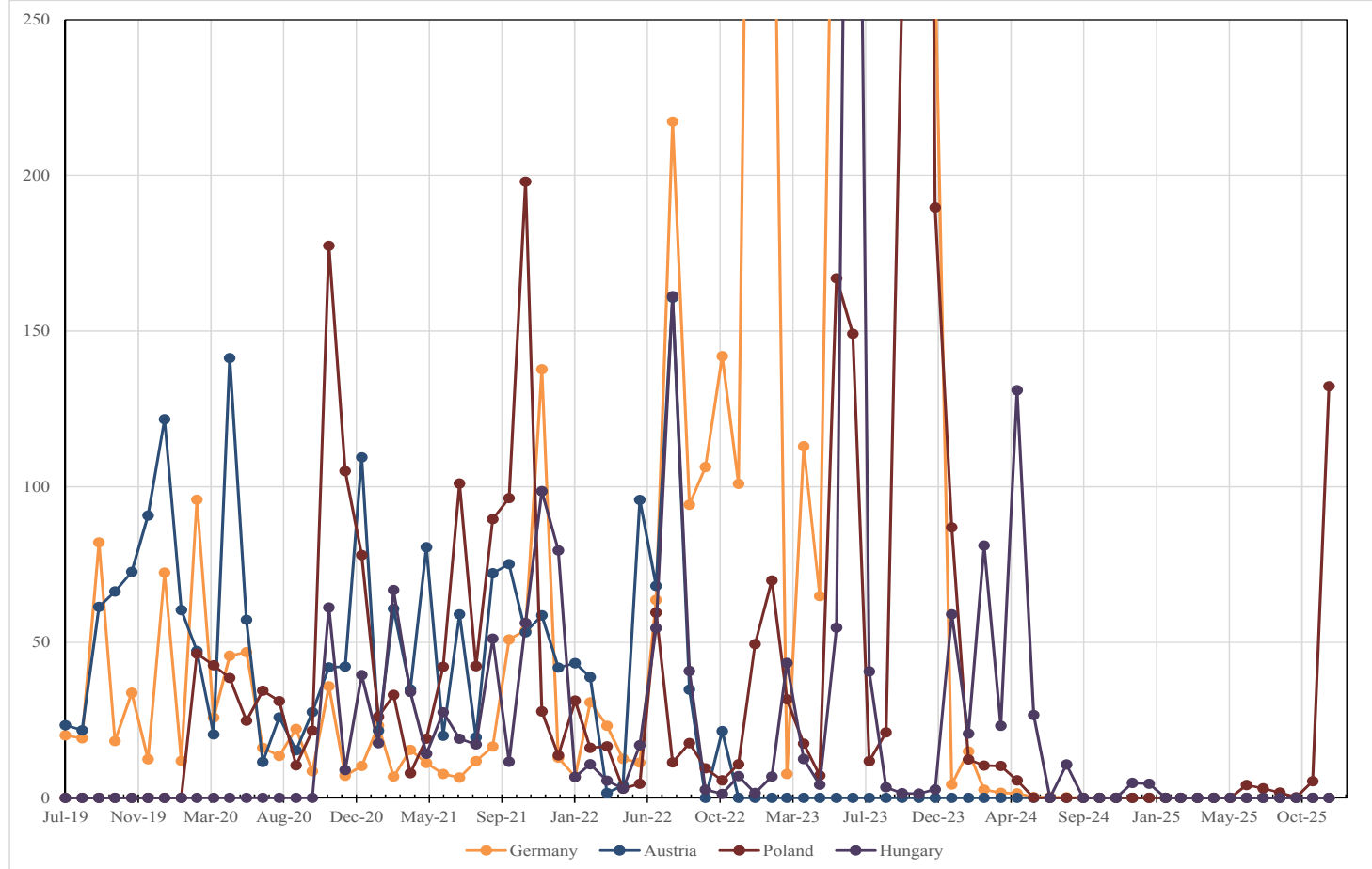

Note: Values for all countries are expressed relative to the RV measure for the Netherlands in July 1919. 
Figure 5. The Responsiveness of Inflation to Uncertainty - Hyperinflation Sample (Impulse Response Functions)

Germany

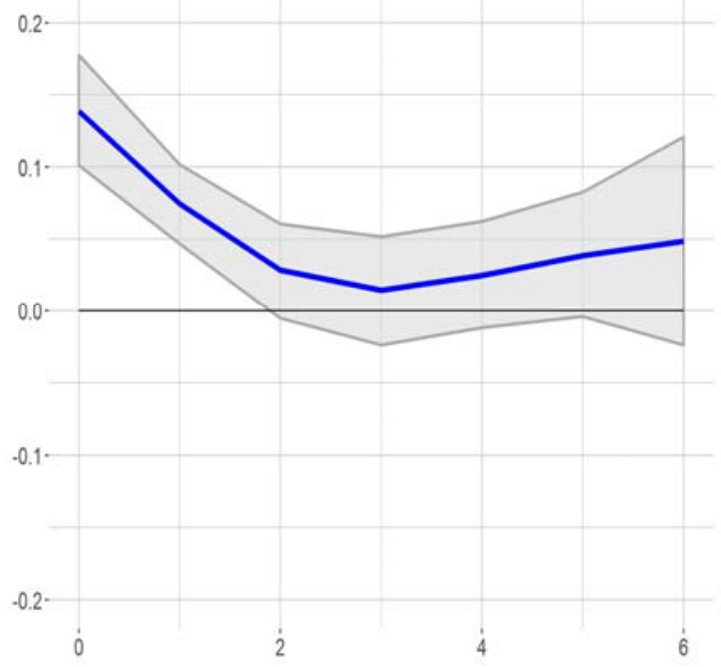

Poland

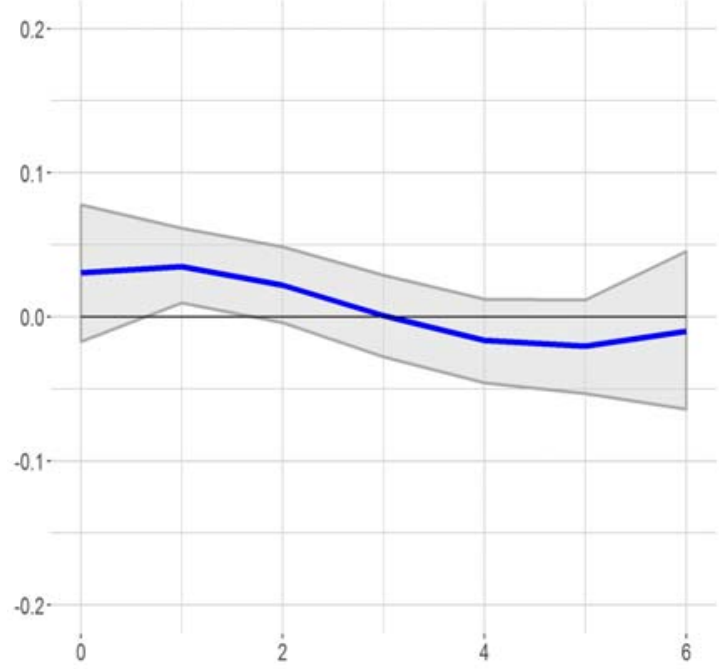

Austria

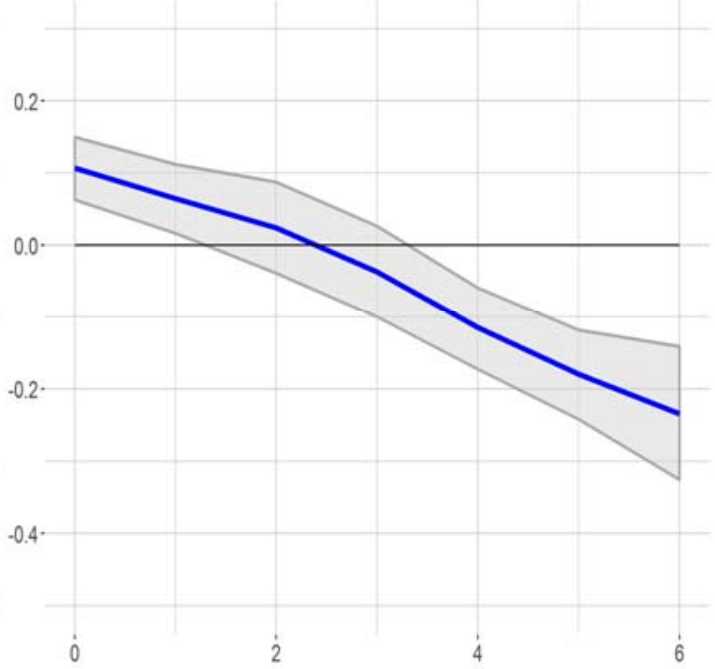

Hungary

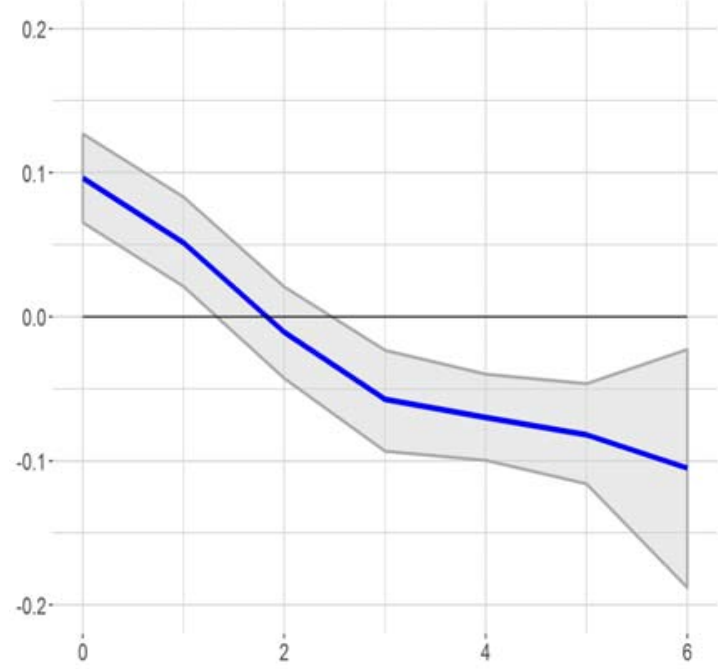

The graphs show the impulse response functions of a one-standard-deviation change in $\Delta \mathrm{R} \mathrm{V}_{\mathrm{kt}}$ on $\Delta \pi_{\mathrm{kt}+\mathrm{j}}$ based on smoothed local projections (SLP), and as described in the text. The grey lines represent the $95 \%$ confidence intervals around the SLP regression coefficients. 
Figure 6. The Responsiveness of Inflation to Uncertainty - Other European Countries (Impulse Response Functions)

Britain

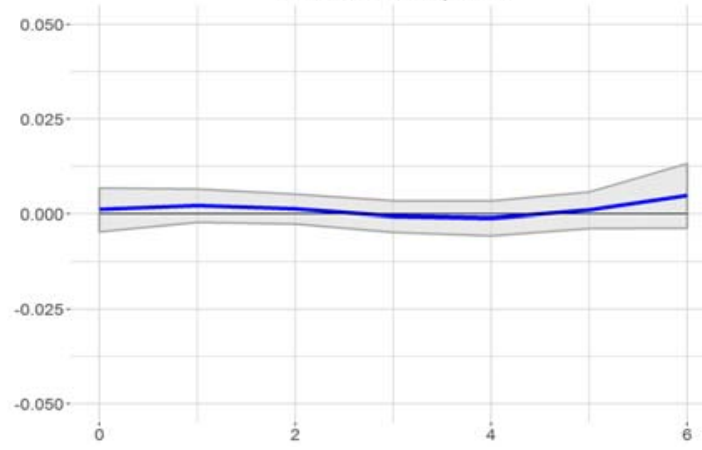

Czechoslovakia

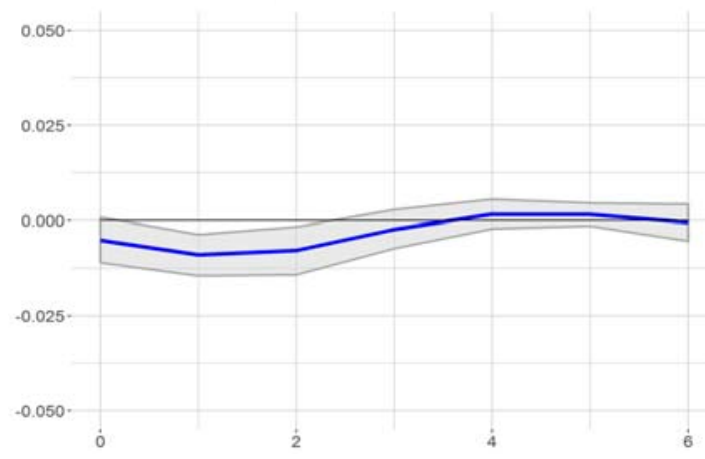

The Netherlands

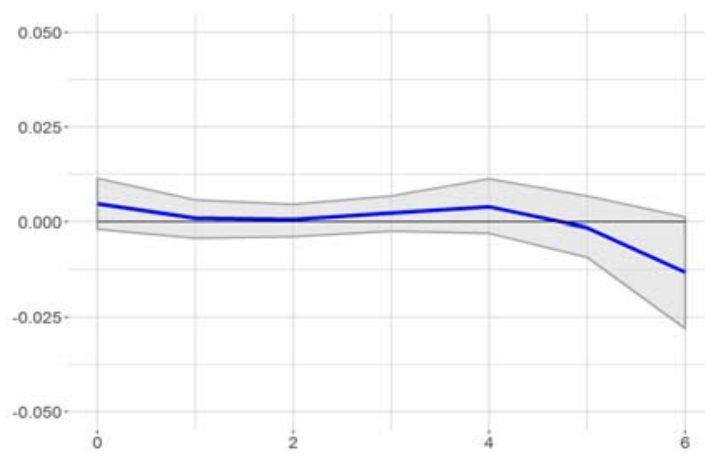

Belgium

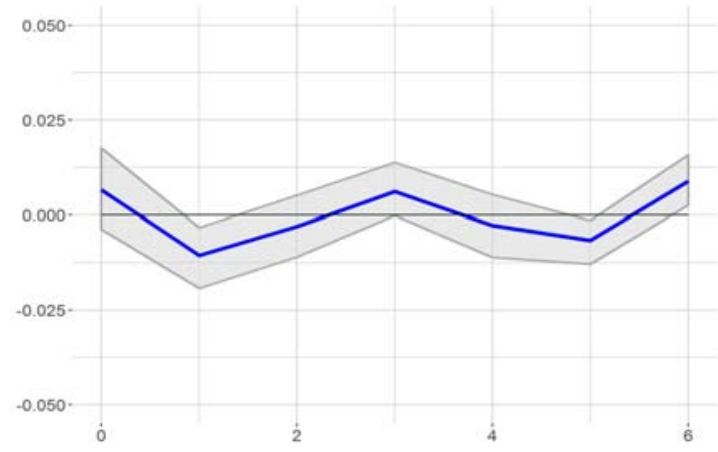

France

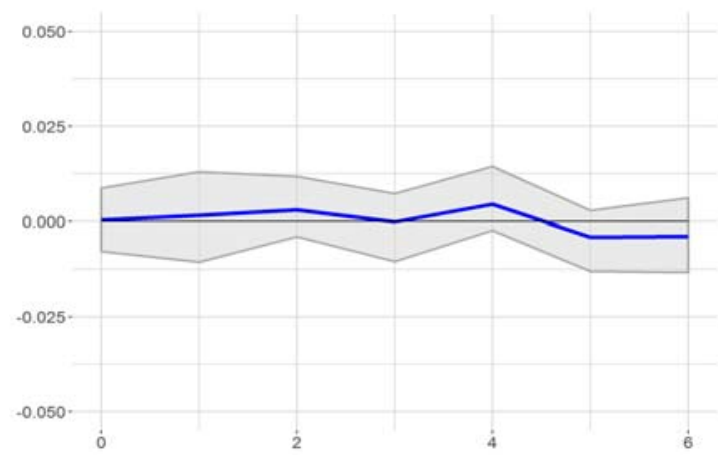

Italy

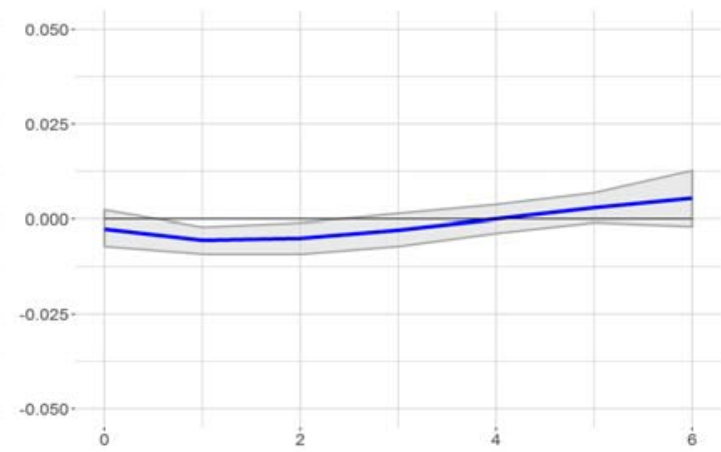

The graphs show the impulse response functions of a one-standard-deviation change in $\Delta \mathrm{R} V_{\mathrm{kt}}$ on $\Delta \pi_{\mathrm{kt}+\mathrm{j}}$ based on smoothed local projections (SLP), and as described in the text. The grey lines represent the $95 \%$ confidence intervals around the SLP regression coefficients. 
Table 1. Debt and Inflation in Post- WWI Europe

\begin{tabular}{l|cc|c|} 
& \multicolumn{2}{|c|}{ Debt-to-GDP ratio } & $\begin{array}{c}\text { Annual } \\
\text { inflation } \\
(1914-1918)\end{array}$ \\
\hline Austria & $63.3 \%$ & -- & $13.5 \%$ \\
Belgium & $49.5 \%$ & $102.7 \%$ & $25.2 \%$ \\
France & $66.3 \%$ & $185.5 \%$ & $30.0 \%$ \\
Germany & $42.1 \%$ & -- & $17.9 \%$ \\
Holland & $61.6 \%$ & $59.6 \%$ & $33.1 \%$ \\
Hungary & -- & -- & $53.7 \%$ \\
Italy & $69.2 \%$ & $142.3 \%$ & $36.3 \%$ \\
UK & $25.8 \%$ & $130.7 \%$ & $20.6 \%$ \\
Poland & -- & -- & $66.4 \%$
\end{tabular}

Note: Debt-to-GDP ratios are from Reinhart and Rogoff (2008). Hungary and Poland were not distinct countries in 1913. The annual inflation rates are calculated by the authors based on data from Statistiches Handbuch der Weltwirtschaft.

Table 2. Uncertainty in Europe after World War I (Average annual realized volatility)

\begin{tabular}{|l|c|c|c|c|c|c|c|c|c|c|}
\hline & Austria & Germany & Hungary & $\underline{\text { Poland }}$ & $\underline{B \text { Belgium }}$ & $\underline{\text { Britian }}$ & $\underline{\text { Czech. }}$ & $\underline{\text { France }}$ & Netherlands & $\underline{\text { Italy }}$ \\
\hline 1919 & 56.07 & 31.00 & --- & --- & 4.31 & 1.15 & -- & 5.72 & 0.58 & 3.43 \\
\hline 1920 & 51.07 & 33.51 & 35.07 & 53.26 & 4.77 & 1.49 & 29.27 & 6.53 & 0.89 & 8.17 \\
\hline 1921 & 55.42 & 29.35 & 37.80 & 63.46 & 5.49 & 0.40 & 8.44 & 2.70 & 0.41 & 3.64 \\
\hline 1922 & 46.41 & 65.54 & 32.53 & 16.65 & 1.71 & 0.14 & 7.86 & 1.76 & 0.10 & 2.40 \\
\hline 1923 & --- & $1,217.26$ & 59.78 & 162.98 & 3.73 & 0.08 & 0.34 & 2.46 & 0.07 & 0.96 \\
\hline 1924 & --- & 2.35 & 29.77 & 10.50 & 7.57 & 0.13 & 0.29 & 6.08 & 0.08 & 0.45 \\
\hline 1925 & 0.01 & --- & 0.38 & 12.24 & 0.58 & 0.01 & 0.00 & 1.36 & 0.00 & 1.42 \\
\hline
\end{tabular}

Note: Monthly realized volatility (RV) is computed using daily exchange rate data. Annual averages are simple means of the monthly values for a given year. All figures are expressed relative to the Netherlands value for July 1919, as described in the text. 
Table 3. News in Germany, Austria, Poland and Hungary for Highest RV Months

Panel A.

Germany Month Rank

Sep-19 18 Constitution of August 1919 gave control over taxation to federal authorities

Jan-20 $19 \quad$ Versailles Treaty comes into force

Mar-20 $16 \quad$ Kapp Putsch. Ruhr uprising by Communists.

Dec-21 12 Chancellor Wirth requests payment moratorium just 6 months after the first payment under the London Ultimatum

Aug-22 10 The Allied Reparations Commission unanimously decided to grant a 6month moratorium on reparations payments

Sep-22 17 The Reichsbank was closed by police following a bank run by employers looking to meet overdue payrolls

Oct-22 14 Chancellor Wirth submitted a question to the cabinet council as to whether

Nov-22 Chancellor Wirth's complete moratorium efforts failed, and he is forced to resign on Nov.14

Dec-22 15 New German proposal of a 5-year moratorium on reparations payments

Jan-23 5 France occupied the Ruhr to ensure payment of war reparations in kind

Feb-23 8 Striking railway workers in the Ruhr began returning to their jobs as German resistance faltered

Apr-23 13 Dr. Cuno's government was spending more than $7 \mathrm{x}$ the amount received as revenue

Jun-23 $\quad 7 \quad$ Germany asked for a new reparations conference

Jul-23 6 France notified Britain that it would not accept an international conference to discuss the German reparations problems

Aug-23 4 Dr. Cuno left office

Sep-23 2 The German government declared a state of emergency under Article 48 of the Weimar Constitution

Oct-23 1 The cabinet of Chancellor Stresemann resigned due to Social Democrats joining the Communists in call for lifting martial law

Nov-23 3 Chancellor Stresemann resignws after a vote of no confidence from members of the government

Dec-23 9 A new Cabinet is formed under Dr. Wilhelm Marx

Oct-24 An international loan is granted to Germany to help the reconstruction of Germany's economy and industry 


\section{Panel B.}

Austria

Month Rank

Sep-19 13 The Treaty of Saint-Germain-en-Laye was signed

Oct-19 $\quad 12$ The treaty was ratified by parliament

Nov-19 9 Emperor Karl returned to Vienna to lead a constitutional committee

Dec-19 6 Minister of Labor Hanusch introduces the Eight-Hour Act in order to limit the work day

Jan-20 3 Vienna runs out of coal, shutting down electric tramcars

Feb-20 $\quad 15$ New tax revenues pre-paid collected, but half sent to reparations

Mar-20 $20 \quad$ Austria and South Tirol are formally reunited

May-20 2 200,000 person street march and protest against a proposed tax on capital on May 11

Jun-20 $\quad 18$ The government of State Chancellor Karl Renner ends

Jan-21 4 Austrian government declares itself insolvent

Mar-21 14 Reparations Commission holds conference with Austria on budget situation and financial relief

May-21 7 Threat of secession crisis in May and June at several Austrian provinces

Jul-21 $16 \quad$ League of Nations recommended a loan, authorized if liens removed.

Sep-21 $10 \quad$ Regular Hungarian troops reoccupied Burgenland

Oct-21 8 Bauer introduced the Social Democratic Financial Plan, increasing taxes / decreasing government expenditures

Nov-21 19 Finance minister announced budget with deficit 3 times larger than estimated in July

Dec-21 17 Plebiscite to determine fate of Burgenland; Austria received most of it

Jun-22 5 Finance Minister Dr. Guertler is forced to retire after protest against the new customs tariff

Jul-22 $11 \quad---$

Aug-22 1 Allied Powers ask League of Nations to intervene as Austria had exhausted all foreign borrowing possibilities 


\begin{tabular}{|c|c|c|}
\hline Month & Rank & \\
\hline Mar-20 & 18 & Polish currencies and administration were unified \\
\hline Apr-20 & 19 & Polish Kiev Offensive with the Soviet Red Army are not successful \\
\hline Nov-20 & 5 & Soviets sued for peace, and the war ended with a ceasefire \\
\hline Dec-20 & 9 & $\begin{array}{l}\text { Belgian diplomats tried to resolve the Lithuanian-Polish dispute on behalf of } \\
\text { the League of Nations }\end{array}$ \\
\hline Jan-21 & 14 & Newspapers reported widespread shortages of food and clothing \\
\hline Jul-21 & 10 & --- \\
\hline Aug-21 & 20 & --- \\
\hline Sep-21 & 12 & --- \\
\hline Oct-21 & 11 & --- \\
\hline Nov-21 & 3 & $\begin{array}{l}\text { League of Nations divided Silesia, with Poland receiving most of the } \\
\text { industrial areas, but about } 1 / 3 \text { rd of the contested land }\end{array}$ \\
\hline Jul-22 & 16 & Poland and Germany concluded a bilateral treaty concerning upper Silesia \\
\hline Jan-23 & 17 & $\begin{array}{l}\text { Lithuania seized the Klaipeda Region; the League of Nations viewed as } \\
\text { adequate compensation for reparations }\end{array}$ \\
\hline Feb-23 & 15 & Formal transfer of the Klaipeda Region to Lithuania \\
\hline Jun-23 & 6 & Chancellor Sikorski overthrown; new cabinet led by Witos installed \\
\hline Jul-23 & 7 & Witos failed to secure $\$ 100 \mathrm{~m}$ loan from Hallgarten \& Co. (US firm) \\
\hline Oct-23 & 2 & Witos government resigns; worker protests widespread \\
\hline Nov-23 & 1 & $\begin{array}{l}\text { Decision to use foreign exchange reserves to arrest exchange rate } \\
\text { depreciation }\end{array}$ \\
\hline Dec-23 & 4 & $\begin{array}{l}\text { Parliament passed a taxation adjustment based on a unit with a fixed value } \\
\text { (the reference zloty) }\end{array}$ \\
\hline Jan-24 & 13 & $\begin{array}{l}\text { Prime Minister asked to use the remaining FX reserves to support the } \\
\text { currency }\end{array}$ \\
\hline Dec-25 & 8 & $\begin{array}{l}\text { Negotiated treaty of mutual assistance with France in the event of an attack } \\
\text { by Germany }\end{array}$ \\
\hline
\end{tabular}




\section{Panel D.}

\begin{tabular}{|c|c|c|}
\hline Date & $\underline{\text { Rank }}$ & \\
\hline Nov-20 & 8 & National Assembly reluctantly ratified the Treaty of Trianon \\
\hline Jan-21 & 17 & $\begin{array}{l}\text { Hungary requested help for mediation of western border conflict with } \\
\text { Austria }\end{array}$ \\
\hline Mar-21 & 7 & Charles I, the former king, first coup attempt began on March 26 \\
\hline Apr-21 & 18 & Prime Minister Teleki was forced to resign after the failed coup \\
\hline Jun-21 & 19 & $\begin{array}{l}\text { Establishment a government-run note institution with limitations on } \\
\text { issuance and prohibitions on lending to the government }\end{array}$ \\
\hline Sep-21 & 13 & Border dispute heightened with Austria \\
\hline Nov-21 & 10 & Charles I's second coup attempt \\
\hline Dec-21 & 4 & Plebiscite to determine fate of Burgenland; Austria received most of it \\
\hline Jan-22 & 6 & $\begin{array}{l}\text { Prime Minister Kallay announced budget deficit nearly double what was } \\
\text { expected }\end{array}$ \\
\hline Jul-22 & 12 & --- \\
\hline Aug-22 & 2 & Cabinet met in an extraordinary session to consider the "Austrian" problem \\
\hline Sep-22 & 15 & Admitted to League of Nations; necessary step for obtaining loans. \\
\hline Mar-23 & 14 & Representatives visited the Bank of England for financial help \\
\hline Jun-23 & 11 & Presentation to the Reparations Commission on inability to pay \\
\hline Jul-23 & 1 & Negotiations for loan from League of Nations in progress \\
\hline Aug-23 & 16 & League reviewing Hungary's financial situation. \\
\hline Jan-24 & 9 & Ratified terms of a League loan \\
\hline Mar-24 & 5 & $\begin{array}{l}\text { Final negotiations of League loan, including borders and reparations } \\
\text { schedule }\end{array}$ \\
\hline May-24 & 3 & Arrangements for League loan made \\
\hline Jun-24 & 20 & League loan floated \\
\hline
\end{tabular}

Note: Data are displayed chronologically for the 20 months with the highest realized volatility for each country. Column 2 shows the country-specific RV rank for a given month. 
Table 4. Model Estimation Sample Periods

\begin{tabular}{cccccc} 
Country & Start date & Reason & End date & Reason & \# months \\
\hline Austria & 1921-Jan & Monthly CPI starts & 1922-Sep & $\begin{array}{c}\text { Month before League of } \\
\text { Nations loan and control }\end{array}$ & 21 \\
Germany & 1920-Apr & Monthly WPI starts & 1923-Jun & $\begin{array}{c}\text { Month before defined } \\
\text { hyperinflation }\end{array}$ & 39 \\
Hungary & 1922-Nov & Monthly WPI starts & 1924-Jun & $\begin{array}{c}\text { New central bank } \\
\text { commences operations; } \\
\text { realized volatility near }\end{array}$ & 20 \\
Poland & 1920-Sep & Monthly WPI starts & 1923-Sep & $\begin{array}{c}\text { Month before defined } \\
\text { hyperinflation }\end{array}$ & 37 \\
\hline Britain & 1919-July & Monthly RV starts & 1924-Dec & Monthly notes data ends & 66 \\
Belgium & 1921-Jan & Monthly WPI starts & 1925-Apr & Monthly notes data ends & 52 \\
Czech. & 1921-Feb & Monthly WPI starts & 1925-Apr & Monthly notes data ends & 51 \\
France & 1919-Jul & Monthly RV starts & 1924-Dec & Monthly notes data ends & 66 \\
Holland & 1920-Jan & Monthly WPI starts & 1925-Apr & Monthly notes data ends & 64 \\
Italy & 1919-Jul & Monthly RV starts & 1924-Nov & Monthly notes data ends & 66
\end{tabular}

Notes: The "Reason" columns explain the binding date availability restrictions. 
Table 5. The Correlation between Changes in Inflation and Lagged Changes in Realized Volatility

Lag value $\mathbf{j}$

\begin{tabular}{lccccccc} 
Country & $\mathbf{0}$ & $\mathbf{1}$ & $\mathbf{2}$ & $\mathbf{3}$ & $\mathbf{4}$ & $\mathbf{5}$ & $\mathbf{6}$ \\
\hline Austria & $0.27^{*}$ & 0.11 & $0.23^{*}$ & 0.26 & $-0.36^{*}$ & -0.22 & -0.17 \\
& 0.2 & 0.22 & 0.22 & 0.22 & 0.27 & 0.26 & 0.26 \\
Germany & $0.38^{*}$ & $0.24^{*}$ & 0.01 & -0.08 & 0.15 & $0.17^{*}$ & 0.13 \\
& 0.14 & 0.15 & 0.16 & 0.17 & 0.17 & 0.17 & 0.17 \\
Hungary & $0.25^{*}$ & $0.51^{*}$ & 0.09 & -0.16 & 0.04 & -0.21 & -0.27 \\
& 0.21 & 0.17 & 0.23 & 0.25 & 0.25 & 0.27 & 0.29 \\
Poland & 0.06 & $0.25^{*}$ & 0.09 & -0.07 & -0.08 & $-0.20^{*}$ & 0 \\
& 0.16 & 0.16 & 0.17 & 0.17 & 0.18 & 0.18 & 0.18 \\
\hline Britain & -0.06 & 0.03 & 0.06 & -0.04 & -0.08 & -0.03 & 0.02 \\
& 0.12 & 0.13 & 0.13 & 0.13 & 0.13 & 0.13 & 0.13 \\
Belgium & $0.20^{*}$ & $-0.23^{*}$ & -0.05 & 0.11 & -0.03 & $-0.18^{*}$ & $0.22^{*}$ \\
& 0.13 & 0.15 & 0.14 & 0.14 & 0.14 & 0.15 & 0.14 \\
Czech. & -0.01 & -0.09 & $-0.27^{*}$ & -0.02 & 0.07 & 0.07 & 0.04 \\
& 0.14 & 0.14 & 0.15 & 0.14 & 0.15 & 0.15 & 0.15 \\
France & 0.07 & 0.01 & 0.13 & -0.06 & $0.15^{*}$ & -0.02 & -0.08 \\
& 0.12 & 0.12 & 0.12 & 0.13 & 0.13 & 0.13 & 0.13 \\
Holland & $0.23^{*}$ & $-0.22^{*}$ & $0.21^{*}$ & $-0.25^{*}$ & $0.21^{*}$ & 0.07 & $-0.22^{*}$ \\
& 0.12 & 0.13 & 0.12 & 0.14 & 0.12 & 0.13 & 0.14 \\
Italy & $0.23^{*}$ & $-0.31^{*}$ & $0.18^{*}$ & -0.09 & -0.01 & 0.03 & 0.13 \\
& 0.12 & 0.14 & 0.12 & 0.13 & 0.13 & 0.13 & 0.13
\end{tabular}

Note: Correlations are for $\rho\left(\Delta \pi_{\mathrm{kt}}, \Delta \mathrm{R} \mathrm{V}_{\mathrm{kt}-\mathrm{j}}\right)$ as described in the text. Asterisks denote statistical significance at the $10 \%$ level. 
Table 6. The Contemporaneous Effect of an Uncertainty Shock on Inflation

\begin{tabular}{|c|c|c|c|c|c|c|}
\hline Country & $\begin{array}{c}\text { RV } \\
\text { std.dev } \\
\text { (ln delta) }\end{array}$ & $\begin{array}{c}\text { RV } \\
\text { change } \\
(\%) \\
\end{array}$ & Coefficient & $\begin{array}{l}\text { Effect } \\
(\ln \\
\text { delta }) \\
\end{array}$ & $\begin{array}{c}\text { \# inflation } \\
\text { std }\end{array}$ & $\begin{array}{c}\text { Inflation change } \\
(\%)\end{array}$ \\
\hline Germany & 1.21 & 235.3 & 0.139 & 0.168 & 0.65 & 7.90 \\
\hline Austria & 1.32 & 272.7 & 0.107 & 0.140 & 0.61 & 17.10 \\
\hline Hungary & 1.72 & 455.8 & 0.096 & 0.165 & 0.91 & 15.28 \\
\hline Poland & 1.21 & 235.3 & 0.031 & 0.037 & 0.18 & 8.04 \\
\hline Britain & 1.17 & 223.4 & 0.001 & 0.001 & 0.05 & -0.50 \\
\hline Belgium & 1.25 & 248.6 & 0.007 & 0.008 & 0.13 & 0.85 \\
\hline Czech. & 1.88 & 556.5 & -0.005 & -0.010 & -0.25 & -0.80 \\
\hline France & 1.07 & 190.8 & 0.000 & 0.000 & 0.01 & 0.00 \\
\hline Netherland & 1.15 & 214.7 & 0.005 & 0.005 & 0.06 & 1.13 \\
\hline Italy & 1.01 & 174.6 & -0.003 & -0.003 & -0.04 & 1.08 \\
\hline
\end{tabular}

Note: Estimates are based on smoothed local projections as described in the text.

The table presents the authors' calculations of the effect of an uncertainty shock in country k (i.e., an innovation to $\Delta \ln \left(R V_{\mathrm{kt}}\right)$ on the contemporaneous change in its inflation rate $\Delta \ln \left(\pi_{\mathrm{kt}}\right)$ using the smoothed local projections model of Equation (2). The first column presents the magnitude of a one standard deviation change in $\Delta \ln \left(R V_{k t}\right)$ based on each country's $R V$ series over the sample periods defined in Table 4. The second column translates that increase into a percentage increase in the level of the $R V_{k t}$ series. The third column reports the SLP estimation coefficients of the contemporaneous change in $\Delta \ln \left(R V_{k t}\right)$ on $\Delta \ln \left(\pi_{k t}\right)$. The fourth column is the product of the first and third columns, which is the numerical effect of a one standard deviation increase of the contemporaneous change in $\Delta \ln \left(R V_{k t}\right)$ on $\Delta \ln \left(\pi_{k t}\right)$. The fifth column transforms the numerical effect into standard deviations of $\Delta \ln \left(\pi_{\mathrm{kt}}\right)$. The last column presents the transformation of the model-implied effect on $\Delta \ln \left(\pi_{\mathrm{kt}}\right)$ into a percentage increase in the level of the $\pi_{\mathrm{kt}}$ series. 
Table 7. The Effect of an Uncertainty Shock on Inflation One Month Forward

\begin{tabular}{|c|c|c|c|c|c|c|}
\hline Country & $\begin{array}{l}\text { RV std.dev } \\
\text { (ln delta) }\end{array}$ & $\begin{array}{c}\text { RV \% } \\
(\%) \\
\end{array}$ & Coefficient & $\begin{array}{c}\text { Effect } \\
(\ln \\
\text { delta }) \\
\end{array}$ & $\begin{array}{c}\text { \# inflation } \\
\text { std }\end{array}$ & $\begin{array}{c}\begin{array}{c}\text { Inflation } \\
\text { change }\end{array} \\
(\%)\end{array}$ \\
\hline Germany & 1.21 & 235.3 & 0.064 & 0.078 & 0.30 & 3.32 \\
\hline Austria & 1.32 & 272.7 & 0.006 & 0.007 & 0.03 & 9.65 \\
\hline Hungary & 1.72 & 455.8 & 0.071 & 0.122 & 0.67 & 15.12 \\
\hline Poland & 1.21 & 235.3 & 0.053 & 0.064 & 0.31 & 4.71 \\
\hline Britain & 1.17 & 223.4 & 0.003 & 0.004 & 0.00 & 0.00 \\
\hline Belgium & 1.25 & 248.6 & -0.006 & -0.008 & -0.12 & -0.40 \\
\hline Czech. & 1.88 & 556.5 & -0.002 & -0.003 & -0.08 & -1.10 \\
\hline France & 1.07 & 190.8 & 0.002 & 0.002 & 0.05 & 0.00 \\
\hline Netherland & 1.15 & 214.7 & -0.008 & -0.009 & -0.10 & 0.04 \\
\hline Italy & 1.01 & 174.6 & -0.020 & -0.020 & -0.33 & -0.97 \\
\hline
\end{tabular}

Note: Estimates are based on smoothed local projections as described in the text.

The table presents the authors' calculations of the effect of a one-month-lagged uncertainty shock in country k (i.e., an innovation to $\Delta \ln \left(R V_{k t}\right)$ on the change in its inflation rate $\Delta \ln \left(\pi_{\mathrm{kt}+1}\right)$ using the smoothed local projections model of Equation (2). The first column presents the magnitude of a one standard deviation change in $\Delta \ln \left(R V_{k t}\right)$ based on each country's RV series over the sample periods defined in Table 4. The second column translates that increase into a percentage increase in the level of the $R V_{k t}$ series. The third column reports the SLP estimation coefficients of the lagged change in $\Delta \ln \left(R V_{k t}\right)$ on $\Delta \ln \left(\pi_{\mathrm{kt}+1}\right)$. The fourth column is the product of the first and third columns, which is the numerical effect of a one standard deviation increase of the lagged change in $\Delta \ln \left(R V_{k t}\right)$ on $\Delta \ln \left(\pi_{\mathrm{k} t+1}\right)$. The fifth column transforms the numerical effect into standard deviations of $\Delta \ln \left(\pi_{\mathrm{kt}+1}\right)$. The last column presents the transformation of the model-implied effect on $\Delta \ln \left(\pi_{\mathrm{kt}+1}\right)$ into a percentage increase in the level of the $\pi_{\mathrm{kt}}$ series. 


\section{Appendix Table 1. News in Other European Countries for Highest RV Months}

\section{Panel A.}

$\underline{\text { Belgium }}$

Month

Dec-19

Mar-21

Feb-24

Mar-24

Apr-24

\section{$\underline{\text { Rank }}$}

4 Neutrality ended; credit extended to other nations

2 Sent troops into the Ruhr

5 Cabinet resigns due to trade and exchange rate issues

3 Ended budget calculations based on German reparations

1 Rumors of foreign loan needed to stabilize the currency

\section{Panel B.}

Britain

Month

Jul-19

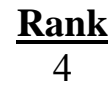

Negotiations with coal miners; concerns on FX rate and humanitarian aid to Europe

Dec-19 2 The Cunliffe Committee recommends an early return to an effective gold standard

Feb-20 1 Chancellor Chamberlain clarified British financial relief to Central Europe

Mar-20 3 The Egyptian legislative assembly passed a resolution demanding independence

Aug-20 $5 \quad$---

\section{Panel C.}

\section{Czechoslovakia}

Month Rank

Mar-20 2 Masaryk presidency-for-life proposed

May-20 4 Masaryk presidency formalized by Parliament

Nov-20 1 Cabinet set to resign; rumored Polish invasion

Coal cut off due to fighting in Upper Silesia; Salzburg votes to join

May-21 3 Germany

Jul-22 $5 \quad---$

\section{Panel D.}

France

Month Rank

Dec-19 2 Military council remains in place after Treaty lapse

Jan-20 3 French and Belgium military and economic alliance deepens

May-20 4 Strike negotiations; rebuilding efforts

Mar-24 1 Reported "bear interest" trade in the franc

May-24 5 French communists to fight the Dawes plan 


\section{Panel E.}

The Netherlands

Month Rank

Jul-19 5 Dutch ships commandeered by the US Shipping Board are returned

Dec-19 4 Dutch objections raised regarding the Entente's administration of the Rhine

Jan-20 $\quad 1 \quad$ Holland refused to extradite Kaiser Wilhelm to the Allies

Aug-20 2 Political negotiations between France and Belgium, with Dutch interests, fail

Sep-20 3 Dutch increase armed forces in light of European uncertainty

\section{Panel F.}

Italy

Month $\underline{\text { Rank }}$

Nov-19 4 Nitti elected Prime Minister

Feb-20 2 PM Nitti suggested not accepting Fiume seaport in Croatia

Apr-20 1 New taxes enacted; civil service strike

May-20 5 cabinets

Nov-20 3 Fiume independence agreed upon, but its leader still moved troops

Note: Data are displayed chronologically for the 5 months with highest realized volatility for each country. Column 2 shows the country-specific RV rank for a given month. 
Appendix Table 2. Data Sources

\begin{tabular}{|c|c|c|c|c|}
\hline & Exchange rates & Price level & IP & Notes circulating \\
\hline Austria & $\begin{array}{c}\text { C\&FC } \\
(1919-1925)\end{array}$ & $\begin{array}{l}\text { Young (1925) (Retail) } \\
\quad \text { (vol. 2, pg. 293) }\end{array}$ & $\begin{array}{l}\text { Monthly Bulletin } \\
\text { (Lignite) } \\
\text { (various) }\end{array}$ & $\begin{array}{l}\text { Young (1925) } \\
\text { (vol. 2,pg. 292) }\end{array}$ \\
\hline Germany & $\begin{array}{c}\text { C\&FC } \\
(1919-1925)\end{array}$ & $\begin{array}{c}\text { Young (1925) } \\
\text { (Wholesale) } \\
\text { (vol. 2,pg. 530) }\end{array}$ & $\begin{array}{l}\text { Monthly Bulletin } \\
\text { (Various) } \\
\text { (various) }\end{array}$ & $\begin{array}{c}\text { Young (1925) } \\
\text { (vol. 2, pg. 526-7) }\end{array}$ \\
\hline Hungary & $\begin{array}{c}\text { C\&FC } \\
(1919-1925)\end{array}$ & $\begin{array}{c}\text { Young (1925) } \\
\text { (Wholesale) } \\
\text { (vol. 2, pg. 322) }\end{array}$ & $\begin{array}{l}\text { Monthly Bulletin } \\
\text { (Lignite) } \\
\text { (various) }\end{array}$ & $\begin{array}{l}\text { Young (1925) } \\
\text { (vol. 2, pg. 321) }\end{array}$ \\
\hline Poland & $\begin{array}{c}\text { C\&FC } \\
(1919-1925)\end{array}$ & $\begin{array}{c}\text { Young (1925) } \\
\text { (Wholesale) } \\
\text { (vol. 2, pg. 349) }\end{array}$ & $\begin{array}{c}\text { Monthly Bulletin (Steel) } \\
\text { (various) }\end{array}$ & $\begin{array}{c}\text { Young (1925) } \\
\text { (vol. 2, pg. 347-8) }\end{array}$ \\
\hline Britain & $\begin{array}{c}\text { C\&FC } \\
(1919-1925)\end{array}$ & $\begin{array}{c}\text { Young (1925) } \\
\text { (Wholesale) } \\
\text { (vol. 2, pg. 449-50) }\end{array}$ & $\begin{array}{l}\text { Monthly Bulletin } \\
\text { (Various) } \\
\text { (various) }\end{array}$ & $\begin{array}{c}\text { Young (1925) } \\
\text { (vol. 2, pg. 446-8) }\end{array}$ \\
\hline Belgium & $\begin{array}{c}\text { C\&FC } \\
(1919-1925)\end{array}$ & $\begin{array}{c}\text { Young (1925) } \\
\text { (Wholesale) } \\
\text { (vol. 2, pg. 299) }\end{array}$ & $\begin{array}{l}\text { Monthly Bulletin } \\
\text { (Various) } \\
\text { (various) }\end{array}$ & $\begin{array}{l}\text { Young (1925) } \\
\text { (vol. 2, pg. 298) }\end{array}$ \\
\hline Czech. & $\begin{array}{c}\text { C\&FC } \\
(1919-1925)\end{array}$ & $\begin{array}{c}\text { Young (1925) } \\
\text { (Wholesale) } \\
\text { (vol. 2, pg. 307) }\end{array}$ & $\begin{array}{l}\text { Monthly Bulletin } \\
\text { (Lignite) } \\
\text { (various) }\end{array}$ & $\begin{array}{c}\text { Young (1925) } \\
\text { (vol. 2, pg. 305-6) }\end{array}$ \\
\hline France & $\begin{array}{c}\text { C\&FC } \\
(1919-1925)\end{array}$ & $\begin{array}{c}\text { Young (1925) } \\
\text { (Wholesale) } \\
\text { (vol. 2, pg. 474) }\end{array}$ & $\begin{array}{l}\text { Monthly Bulletin } \\
\text { (Various) } \\
\text { (various) }\end{array}$ & $\begin{array}{c}\text { Young (1925) } \\
\text { (vol. 2, pg. 470-2) }\end{array}$ \\
\hline Holland & $\begin{array}{c}\text { C\&FC } \\
(1919-1925)\end{array}$ & $\begin{array}{c}\text { Young (1925) } \\
\text { (Wholesale) } \\
\text { (vol. 2, pg. 330) }\end{array}$ & $\begin{array}{l}\text { Monthly Bulletin } \\
\text { (Various) } \\
\text { (various) }\end{array}$ & $\begin{array}{c}\text { Young (1925) } \\
\text { (vol. 2, pg. 327-9) }\end{array}$ \\
\hline Italy & $\begin{array}{c}\text { C\&FC } \\
(1919-1925)\end{array}$ & $\begin{array}{c}\text { Young (1925) } \\
\text { (Wholesale) } \\
\text { (vol. 2, pg. 504) }\end{array}$ & NA & $\begin{array}{c}\text { Young (1925) } \\
\text { (vol. 2, pg. 494-5) }\end{array}$ \\
\hline
\end{tabular}

Note: Exchange rates were sourced from the monthly tables reported in the Commercial and Financial Chronicle. National price levels, whether retail or wholesale, were sourced from Young (1925), as where national notes in circulation. National industrial production (IP) was sourced from the League of Nations' Monthly Bulletin of Statistics. Since no single series was available, the IP growth series are a weighted average of available production series for coal, lignite, pig iron, and steel (unless only a single series is available as noted). 